\title{
ECONOMICS
}

\section{UNDERSTANDING WORLD COMMODITY PRICES Returns, Volatility and Diversification}

by

\author{
Mei-Hsiu Chen \\ Business School \\ The University of Western Australia
}

DISCUSSION PAPER 09.03 


\title{
UNDERSTANDING WORLD COMMODITY PRICES \\ Returns, Volatility and Diversification
}

\author{
by \\ Mei-Hsiu Chen ${ }^{1}$ \\ UWA Business School \\ The University of Western Australia
}

Paper Date: August 2008

\begin{abstract}
$\underline{\text { Abstract }}$
In recent times, the prices of internationally-traded commodities have reached record highs and there is considerable uncertainty regarding their future. This phenomenon is partially driven by strong demand from a small number of emerging economies, such as China and India. This paper places the recent commodity price boom in historical context, drawing on an investigation of the long-term time-series properties, and presents unique features for 33 individual commodity prices. Using a new methodology for examining cross-sectional variation of commodity returns and its components, we find strong evidence that the prices of world primary commodities are extremely volatile. In addition, prices are roughly 30 percent more volatile under floating than under fixed exchange rate regimes. Finally, using the capital asset pricing model as a loose framework, we find that global macroeconomic risk components have become relatively more important in explaining commodity price volatility.
\end{abstract}

\footnotetext{
1 I would like to acknowledge Professor Kenneth W Clements for supervising this research and providing helpful comments during the write-up of this paper. This paper was financially supported by the UWA Business School and is based on my dissertation for the higher degree by research (HDR) preliminary programme in 2007.
} 


\section{INTRODUCTION}

Primary commodities, including raw or partially processed materials that will be transformed into finished goods, are often the most significant source of export earnings for many developing countries. Figure 1 shows the share of internationallytraded non-fuel primary commodity exports in gross domestic product (GDP) for countries around the world. A particularly striking feature in Figure 1 is the importance of these commodities as a source of export earnings for many developing countries. According to the United Nations Conference on Trade and Development (1996), 57 developing countries relied on three commodities for more than half of their total exports in 1995. For these developing countries, producing and exporting primary commodities significantly affect their terms of trade, foreign reserve holdings, government fiscal revenue and public expenditure. Figure 2 shows examples of selected countries whose single most important commodity accounts for more than 50 percent of their export earnings in 1990-1999.

\section{Figure 1}

\section{World Map - Dependence on Non-fuel Primary Commodity Exports (2006)}

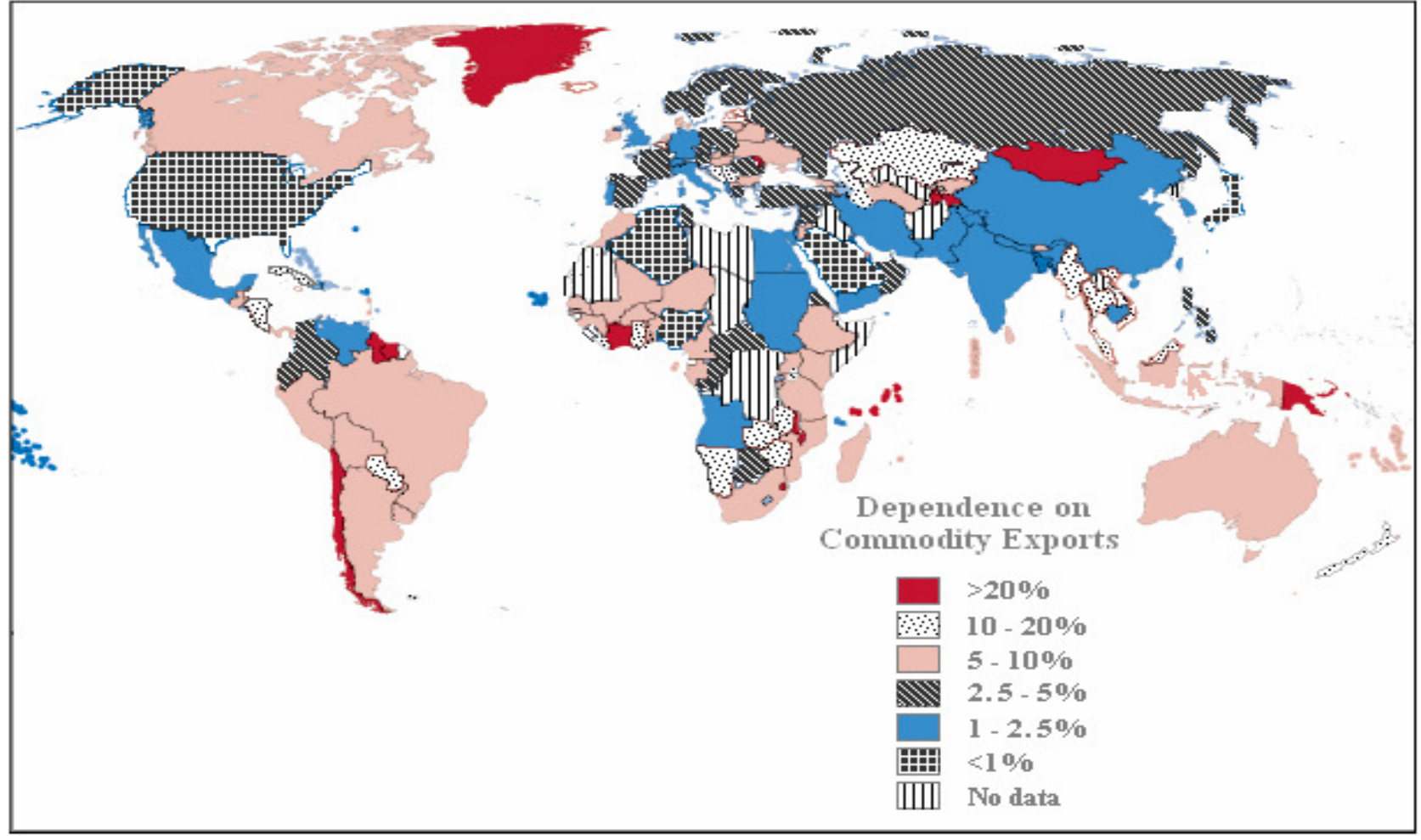

Source: World Bank, World Integrated Trade Solution (WITS) database.

Note: The countries are colour-coded based on total exports of non-fuel primary commodities as a percent of GDP. 
Taking a closer look at Figure 2, we see that five countries depend on one single commodity for more than 90 percent of their total export earnings. The highest export concentration is Dominica, for which bananas account for a staggering 98 percent of total export share. Export shares of many countries are highly concentrated, implying that variation in their terms of trade correlates strongly with the price fluctuations of a few key primary commodities. According to the World Bank's World Development Indicators in 1997, the ratio of primary commodities to total merchandise exports is 42 percent for developing countries. In contrast, commodity dependence is lower for developed countries, where primary commodities accounted for only 19 percent of their total exports in 1997.

Figure 2

Export Share of Most Important Primary Commodity for Selected Countries Averages for 1990-99

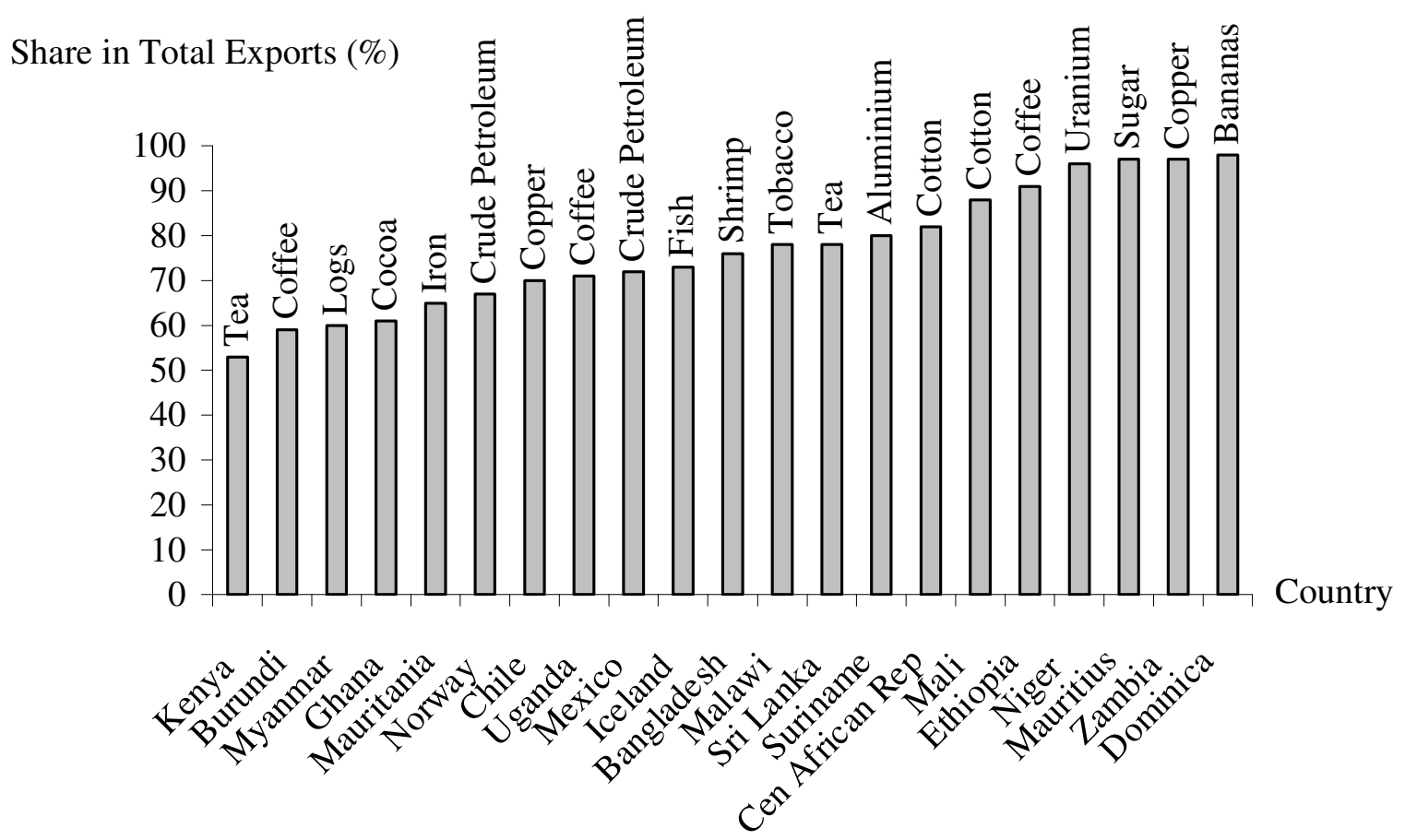

Source: United Nations Commodity Trade Statistics Database (COMTRADE).

The last 20 years has predominantly been a bear market for commodities. However by the turn of the century, the world has witnessed the biggest boom in half a century for both fuel and non-fuel commodity prices accompanied by tremendous 
price volatility. The International Monetary Fund's non-fuel primary commodity price index rose by 149 percent in real terms from January 2000 to June 2006, while the energy and fuel index increased by 191 percent. $^{2}$ Within the non-fuel commodity index, the rise in the metals index is even greater at about 236 percent over the same period. How volatile are prices for primary commodities? As an example, consider the behaviour of the dollar price for sugar from 1948 to 2006 deflated by the United States (US) consumer price index (CPI). The sugar price is chosen for being the most volatile internationally tradable commodity out of 33 commodities examined in this paper. Figure 3 shows no obvious trend in prices; however, there are several distinct sharp peaks, particularly in the early 1960s, the late 1970s and continuing into the early 1980s. In the 1980s, poor harvests in Cuba and the Soviet Union caused prices to rise sharply. ${ }^{3}$ Such instances provide evidence that market abnormalities can cause temporary surges in price volatility. Despite the volatility, the sugar price tends to revert back to its long-run unchanging average. In other words, shocks cause the price to deviate temporarily from this average but do not persist into the indefinite future. That is, the mean-reverting behaviour of sugar price can be explained by the existence of a significant temporary component in the sugar price. One salient feature of the real sugar price that separates it from other price series is the strong appearance of stationarity in the level; whereas typical commodity price series have tendencies of upward or downward trends over time.

In an influential article, Deaton (1999, p. 27) notes: "What commodity prices lack in trend, they make up for in variance." Indeed, variability is large relative to trend for many commodity prices. For instance, the price for sugar in 1974 was almost three times that of the previous year and just over ten times that in 1968. The swing from trough to peak in 1974 took only a few years. Note in Figure 3 that there are several sharp upward spikes but no matching downward spikes, which produces substantial positive skewness in the data. Such a characteristic is common for many primary commodity prices.

2 According to the IMF Commodities Unit Research Department, Indices of Primary Commodity Prices from 1995 to the present. Non-fuel primary commodities have a higher share of world export trade (52.2 percent in 1995-1997) than energy and fuel commodities (47.8 percent). Indices of prices are quoted in terms of nominal US dollars. To convert into real terms, nominal prices are deflated by the US consumer price index for all urban consumers (CPI-U). Available from: $<$ http://www.imf.org/external/np/res/commod/index.asp> [25 April 2007].

3 Since 1991, the Soviet Union is known as the "Union of Soviet Socialist Republics". 


\section{Figure 3}

\section{Real Price for Sugar, 1948-2006}

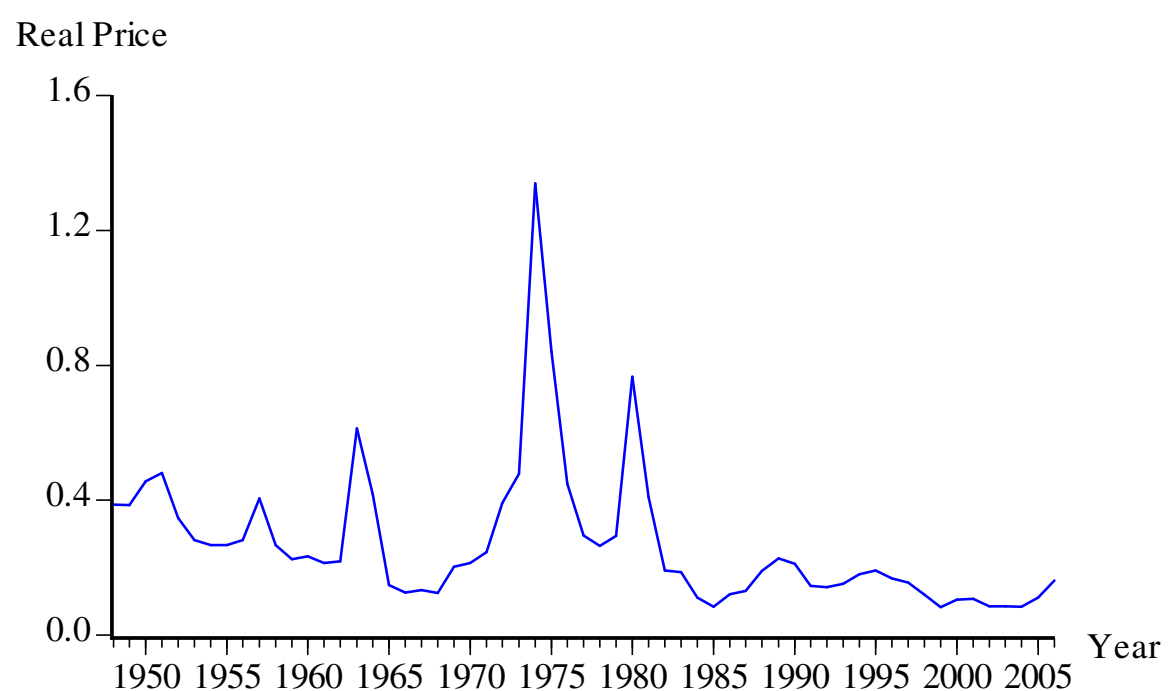

Source: Bidarkota and Crucini (2000) and the World Bank, Development Prospects Group primary commodity price databases.

Note: The underlying data are average prices for each year, deflated by the US CPI-U.

World commodity prices have risen significantly since the turn of the millennium. However, the serious problem of volatile price uncertainty facing commodity-dependent exporting countries has not disappeared. Previous research on commodity returns has arrived at a remarkable degree of consensus such that real prices have exhibited increasing variability since the breakdown of the Bretton Woods fixed exchange rate system. It has long been noted that commodity price volatility has exceeded that of exchange rates and interest rates. Kroner et al. (1993) show that over the period 1972 to 1990 , non-fuel commodity price volatility as measured by the standard deviation of price changes has not been below 15 percent and peaked at more than 50 percent per annum in 1975. In addition, short-term commodity prices can be extremely volatile, with prices changing by as much as 50 to 100 percent in a single year. For evidence on commodity price fluctuations see, for example, Chu and Morrison (1984), Deaton and Laroque (1992), Yamey (1992), Reinhart and Wickham (1994), Cuddington and Liang (1999), Deaton (1999) and Cashin and McDermott (2002).

Today, in spite of knowledge of several stylised facts about the properties of world commodity prices, there remain large gaps in our understanding of their behaviour. Prior empirical work on primary commodity prices mainly focuses on the 
question of whether the statistical evidence points to a long-term trend. Unfortunately, not many papers have sought to investigate the global macroeconomic versus idiosyncratic components behind commodity price variations. This paper, in contrast, carries out an empirical study to shed light on the question of whether the price of individual primary commodities consists mainly of global or idiosyncratic risk that can be mitigated through proper diversification. The need to understand the underlying risk components has taken on a new urgency in recent years as non-fuel primary commodity prices fell sharply and persistently in real terms since 1900 although prices have risen significantly over the past few years. While this price movement affects all commodity-exporting dependent countries to some extent, those with the narrowly-based export bundle suffer the biggest impact. Knowledge of these features would further our understanding of the nature of price movements in world commodity markets that is both relevant and important for the conduct of macroeconomic policy.

Although a substantial amount of prior research relating to risk components focusing on the cross section of average stock returns exists, papers on distinguishing the risk components associated with individual commodity price movements are sparse. A notable exception is the work of Bidarkota and Crucini (2000). Based on their empirical results of 33 primary commodities, they conclude that common and idiosyncratic risk varies dramatically across individual commodities, and that national terms of trade volatility could be reduced substantially by altering the export mix. They further find that countries with high terms of trade volatility tend to have a narrowly-based export bundle specializing in the most volatile primary commodities.

The remainder of this paper is structured as follows. Section 2 provides theoretical background to the analysis. Annual price data and descriptive statistics on 33 commodity prices for the period 1948 through 2006 are discussed in Section 3. In Section 4, we develop a new methodology for examining cross-sectional variations of commodity returns and its two main components, which can be thought of as corresponding to within-group and between-group components. The next section is concerned with the relationship between price changes and the level of volatility of commodity price index. Section 6 uses portfolio theory to distinguish systematic and idiosyncratic risk factors in commodity price variations. The final section offers caveats associated with the findings and provides a brief summary. 


\section{THEORETICAL FOUNDATIONS}

Suppose that there are $n$ commodities with price vector $\boldsymbol{p}=\left(p_{1}, p_{2}, \ldots, p_{n}\right)^{\prime}$ and corresponding quantity vector $\boldsymbol{q}=\left(q_{1}, q_{2}, \ldots, q_{n}\right)^{\prime}$, so that $m=\boldsymbol{p}^{\prime} \boldsymbol{q}=\sum_{i=1}^{n} p_{i} q_{i}$ is the total value. The value share of individual commodity $i$ is $w_{i}=p_{i} q_{i} / m$, which is positive and satisfies $\sum_{i=1}^{n} w_{i}=1$. Taking the differential of $m$ and using the identity that for any positive variable $x, d x / x=d(\log x)$, we have

$$
d(\log m)=\sum_{i=1}^{n} w_{i} d\left(\log q_{i}\right)+\sum_{i=1}^{n} w_{i} d\left(\log p_{i}\right) .
$$

Equation (1) can be written as $d(\log m)=d(\log Q)+d(\log P)$, which is a decomposition of the change in $m$ into indices of overall quantity change and price change, where $d(\log Q)$ and $d(\log P)$ are the Divisia quantity and price indices are defined as $\quad d(\log Q)=\sum_{i=1}^{n} w_{i} d\left(\log q_{i}\right) \quad$ and $\quad d(\log P)=\sum_{i=1}^{n} w_{i} d\left(\log p_{i}\right)$, respectively.

If we define growth rate in the commodity price index and commodity $i$ over the years $t-1$ and $t$ by $D P_{t}=\log P_{t}-\log P_{t-1}$ and $D p_{i t}=\log p_{i t}-\log p_{i, t-1}$, respectively, then these two growth rates can be linked thus

$$
D P_{t}=\sum_{i=1}^{n} \bar{w}_{i t} D p_{i t},
$$

where $\bar{w}_{i t}$ is the arithmetic average value share of commodity $i$ from year $t$ to $t-1$ such that $\bar{w}_{i t}=1 / 2\left(w_{i t}+w_{i, t-1}\right)$. Equation (2) defines the index of prices as weighted firstorder moments of $D p_{1 t}, \ldots, D p_{n t}$. The corresponding second-order moment can be expressed as

$$
\Pi_{t}=\sum_{i=1}^{n} \bar{w}_{i t}\left(D p_{i t}-D P_{t}\right)^{2}
$$

Equation (3) is a weighted variance of the price log changes such that $\Pi_{t}$ increases as the individual price growth rates $\left(D p_{i t}\right)$ differ by more from that of the mean value $\left(D P_{t}\right)$. In other words, $\sqrt{\Pi_{t}}$ represents the cross-sectional standard deviation, or the volatility of the prices. 


\section{Assessing the Risk: Global versus Idiosyncratic Shocks}

The most common approach for measuring price volatility or risk of a primary commodity is the coefficient of variation $(\mathrm{CV})$ of the annual percent changes. However, $\mathrm{CV}$ can be criticized as being a limited measure as the information it conveys is restricted to overall volatility. On the other hand, the capital asset pricing model (CAPM) is a useful framework for distinguishing the extent to which commodity price volatility consists of global versus commodity-specific risk. ${ }^{4}$ The idea behind the CAPM is that investors require compensation for the time value of money and risk. CAPM states that the expected return of a security or a portfolio equals the rate on a risk-free asset plus a risk premium:

$$
E\left(r_{i}\right)=r_{f}+\beta_{i}\left[E\left(r_{m}\right)-r_{f}\right]
$$

where $E\left(r_{i}\right)$ is the expected rate of return on security $i ; r_{f}$ is the rate of return of a theoretical risk-free asset, representing the compensation required by investors for placing money in any investment over a period of time; and $\beta_{i}$ measures the sensitivity of the security return to system-wide global fluctuations. Generally, a higher $\beta_{i}$ corresponds to higher risk, since investors are risk averse and require a higher rate of return to compensate for holding a more risky asset. In other words, $\beta_{i}$ can be used as a volatility measure of the commodity relative to the market. The term $E\left(r_{m}\right)$ in equation (4) is the expected rate of return of the market portfolio, such as the Dow Jones Industrial Average or Standard \& Poor's 500 Index. Accordingly, $E\left(r_{m}\right)-r_{f}$ is the difference between the expected market return and the risk-free rate, i.e., the risk premium, the amount of compensation that an investor needs for taking on additional risk.

In the context of primary commodities, price variation comprises both global risk and idiosyncratic risk. In order to decompose price movements into global and commodity-specific risk components, the annual growth rate $D p_{i t}$ is regressed against some appropriate proxy for the return on a portfolio of commodity prices. For this purpose we use, $D P_{t}$, the annual growth rate of a basket of primary commodities. That is, we estimate

4 The central foundation of the model was first formulated by Markowitz (1959) based on modern portfolio theory, and developed a few years later by Sharp (1964), Lintner (1965) and Mossin (1966) independently. 


$$
D p_{i t}=\alpha_{i}+\beta_{i} D P_{t}+\varepsilon_{i t},
$$

where $\beta_{i}$ measures the elasticity of $p_{i t}$ with respect to $P_{t}$. The value for the coefficient of determination for equation (5), $R^{2}$, is interpreted as the fraction of the variation in the commodity price that is attributable to global fluctuations, as measured by $D P$, while $1-R^{2}$ measures the extent to which variation in prices arises from idiosyncratic factors that are independent of global factors.

\section{DATA: SOURCES, SAMPLE SELECTION AND DESCRIPTION}

Most previous studies in the economics literature use the Grilli and Yang (1988) (hereafter referred to as GY) index of real commodity prices to evaluate long-run commodity price movements. The GY index comprises 24 primary commodity prices running from 1900 through 1986. Unlike those studies, this paper covers a wider range of commodities with annual price data from 1948 to 2006. As our data are more recent, they may provide an opportunity for understanding both long-term and recent commodity price behaviour. Our analysis considers 32 non-fuel commodities plus crude oil that together comprise the bulk of world commodity trade. The data on the 33 commodity prices from 1948 to 1993 are taken from Bidarkota and Crucini (2000). We then used the World Bank Development Prospects Group's primary commodity price databases to supplement the Bidarkota and Crucini (2000) data, providing a dataset from 1948 to $2006 .^{5}$

The data comprise annual nominal commodity prices, and are expressed in terms of US dollars. The real commodity price is obtained by deflating the nominal price by the US CPI-U. ${ }^{6}$ In the subsequent analysis, no smoothing or data cleaning is undertaken for any of the price series. This is because while smoothing may help in the removal of outliers, it may also suppress some of the most important movements in the commodity price data sets.

Before proceeding further, it is helpful to consider some of the salient features of the 33 individual commodity price series. Table 1 reports the ADF results for testing for a unit root in each of the prices. Three comments can be made about the

\footnotetext{
5 The world Bank data are from their Pink Sheet - World Bank Commodity Price Data, various issues. The author gratefully acknowledges the help of Betty Dow in providing these data. Commodity price data are updated monthly by the World Bank. Available from: $<$ http://www.worldbank.org/prospects> [13 May 2007].

6 The US CPI-U is taken from the US Department of Labor Bureau of Statistics. Available from: $<$ http://www.bls.gov> [10 May 2007].
} 
results. First, for 18 out of 33 prices in levels, the results in column 3 indicate the presence of a unit root, as it fails to reject the null hypothesis of a stochastic trend at the 5 percent significance level. Second, after applying the logarithmic transformation, the corresponding $p$-values of the ADF test statistics are significant for only 9 out of 33 cases, providing strong evidence that the null hypothesis of a unit root cannot be rejected. Lastly, the null of a unit root is rejected for all 33 internationally-traded primary commodities when they are expressed in terms of logarithmic first differences. In what follows, in order to induce stationarity, we use logarithmic first differences. Log differences have the additional advantage of being dimensionless.

Table 2 summarizes the data with commodities ranked by increasing mean price changes. The average growth rate over nearly 60 years varies quite dramatically across the 33 commodities and is mostly negative with the exception of seven commodities showing a positive trend. Whilst market conditions differ across commodities, the downward trend is quite generalized, suggesting that common systematic factors may be responsible for the observed price declines. Commodities whose prices have risen over the period belong to the mining and resource sectors, except for crude oil and logs. This is inconsistent with the findings of Clements (2004), who examined 24 commodity prices computed by GY from 1914-1986, only five of which were demonstrated to experience price increases-none belonging to the metals category. This discrepancy is expected due to recent strong international demand for metals, in particular by China and other emerging markets, which have become key drivers of price dynamics in these markets. The rise of China suggests a fundamental change, having the effect of a long-term hardening of metals prices.

The highest annual growth rate of 127 percent was recorded in 1973-74 for phosphate rock, the lowest being -104 percent for copra in $1974-75 .^{7}$ The volatility of

7 Since any positive variable cannot fall by more than 100 percent and still stay positive, it is important to clarify that the underlying data are annual logarithmic changes. For small changes, a log-change, when multiplied by 100 , is approximately a percentage change. The exact relationship between the two types of changes is as follows: write $D p_{i t}=\log p_{i t}-\log p_{i, t-1}$ for the $\log$-change in the price of commodity $i$. Then, the corresponding percentage change is:

$$
\frac{100 \times\left(p_{i t}-p_{i, t-1}\right)}{p_{i, t-1}}=100 \times\left(e^{D p_{i t}}-1\right) \text {. }
$$

Accordingly, the lowest price change is copra for which $D p_{i t}=-1.04$, the implied percentage change is $100 \times\left(e^{-1.04}-1\right)=-65$ percent. 
Table 1

Augmented Dickey-Fuller Unit Root Tests for 33 Real Commodity Prices - Annual Observations, 1948-2006

\begin{tabular}{|c|c|c|c|c|c|c|c|c|c|c|}
\hline & \multirow[b]{2}{*}{$\begin{array}{l}\text { Commodity } \\
\text { (1) }\end{array}$} & \multicolumn{3}{|c|}{ Level } & \multicolumn{3}{|c|}{$\log$} & \multicolumn{3}{|c|}{ Log First Difference } \\
\hline & & $\begin{array}{c}t \text {-stat } \\
(2)\end{array}$ & $\begin{array}{c}p \text {-value } \\
\text { (3) }\end{array}$ & $\begin{array}{c}\text { lags } \\
(4)\end{array}$ & $\begin{array}{c}t \text {-stat } \\
(5)\end{array}$ & $\begin{array}{c}p \text {-value } \\
\text { (6) }\end{array}$ & $\begin{array}{c}\text { lags } \\
(7)\end{array}$ & $\begin{array}{c}t \text {-stat } \\
(8)\end{array}$ & $\begin{array}{c}p \text {-value } \\
(9)\end{array}$ & $\begin{array}{l}\text { lags } \\
(10)\end{array}$ \\
\hline 1. & Aluminium & -4.03 & $0.01 *$ & 1 & -3.87 & $0.02 *$ & 1 & -6.59 & $0.00 * *$ & 0 \\
\hline 2. & Bananas & -3.38 & 0.06 & 0 & -4.05 & $0.01 *$ & 0 & -7.81 & $0.00 * *$ & 1 \\
\hline 3. & Bauxite & -1.73 & 0.72 & 0 & -1.61 & 0.77 & 0 & -7.13 & $0.00 * *$ & 0 \\
\hline 4. & Beef & -2.13 & 0.52 & 0 & -2.03 & 0.57 & 0 & -7.02 & $0.00 * *$ & 0 \\
\hline 5. & Cocoa & -3.02 & 0.14 & 1 & -1.89 & 0.64 & 2 & -7.01 & $0.00 * *$ & 1 \\
\hline 6. & Coconut oil & -1.65 & 0.76 & 4 & -2.77 & 0.22 & 2 & -9.75 & $0.00 * *$ & 1 \\
\hline 7. & Coffee & -3.40 & 0.06 & 0 & -3.11 & 0.11 & 0 & -7.30 & $0.00 * *$ & 0 \\
\hline 8. & Copper & -2.58 & 0.29 & 0 & -2.91 & 0.17 & 1 & -5.69 & $0.00 * *$ & 0 \\
\hline 9. & Copra & -5.45 & $0.00 * *$ & 1 & -2.98 & 0.15 & 2 & -9.49 & $0.00 * *$ & 1 \\
\hline 10. & Cotton & -3.37 & 0.07 & 0 & -2.94 & 0.16 & 0 & -7.67 & $0.00 * *$ & 1 \\
\hline 11. & Crude oil & -1.81 & 0.69 & 0 & -1.79 & 0.70 & 0 & -6.79 & $0.00 * *$ & 0 \\
\hline 12. & Groundnut meal & -3.96 & $0.02 *$ & 0 & -2.48 & 0.34 & 0 & -7.51 & $0.00 * *$ & 1 \\
\hline 13. & Groundnut oil & -3.42 & 0.06 & 0 & -3.30 & 0.08 & 0 & -8.27 & $0.00 * *$ & 1 \\
\hline 14. & Iron ore & -2.92 & 0.16 & 1 & -2.79 & 0.21 & 1 & -4.90 & $0.00 * *$ & 0 \\
\hline 15. & Jute & -4.41 & $0.00 * *$ & 1 & -3.34 & 0.07 & 1 & -8.36 & $0.00 * *$ & 3 \\
\hline 16. & Lead & -3.35 & 0.07 & 0 & -2.54 & 0.31 & 0 & -6.74 & $0.00 * *$ & 0 \\
\hline 17. & Logs & -3.18 & 0.10 & 0 & -2.97 & 0.15 & 0 & -7.55 & $0.00 * *$ & 1 \\
\hline 18. & Maize & -3.68 & $0.03 *$ & 1 & -3.20 & 0.10 & 0 & -7.09 & $0.00 * *$ & 1 \\
\hline 19. & Nickel & -2.40 & 0.38 & 0 & -2.58 & 0.29 & 0 & -6.49 & $0.00 * *$ & 1 \\
\hline 20. & Oranges & -4.48 & $0.00 * *$ & 0 & -3.23 & 0.09 & 0 & -10.22 & $0.00 * *$ & 0 \\
\hline 21. & Palm oil & -2.75 & 0.22 & 2 & -2.07 & 0.55 & 2 & -9.41 & $0.00 * *$ & 1 \\
\hline
\end{tabular}

(Table continues on the next page.) 
Table 1 (continued)

Augmented Dickey-Fuller Unit Root Tests for 33 Real Commodity Prices - Annual Observations, 1948-2006

\begin{tabular}{|c|c|c|c|c|c|c|c|c|c|c|}
\hline & \multirow[b]{2}{*}{$\begin{array}{l}\text { Commodity } \\
\text { (1) }\end{array}$} & \multicolumn{3}{|c|}{ Level } & \multicolumn{3}{|c|}{$\log$} & \multicolumn{3}{|c|}{ Log First Difference } \\
\hline & & $\begin{array}{l}t \text {-stat } \\
(2)\end{array}$ & $\begin{array}{c}p \text {-value } \\
\text { (3) }\end{array}$ & $\begin{array}{c}\text { lags } \\
(4)\end{array}$ & $\begin{array}{l}t \text {-stat } \\
(5)\end{array}$ & $\begin{array}{c}p \text {-value } \\
(6)\end{array}$ & $\begin{array}{c}\text { lags } \\
(7)\end{array}$ & $\begin{array}{c}t \text {-stat } \\
(8)\end{array}$ & $\begin{array}{c}p \text {-value } \\
\text { (9) }\end{array}$ & $\begin{array}{l}\text { lags } \\
(10)\end{array}$ \\
\hline 22. & Phosphate rock & -4.66 & $0.00 * *$ & 1 & -4.02 & $0.01 *$ & 1 & -6.80 & $0.00 * *$ & 1 \\
\hline 23. & Rice & -4.70 & $0.00 * *$ & 1 & -2.46 & 0.34 & 2 & -7.12 & $0.00 * *$ & 1 \\
\hline 24. & Rubber & -4.36 & $0.01 * *$ & 0 & -5.37 & $0.00 * *$ & 1 & -8.69 & $0.00 * *$ & 1 \\
\hline 25 . & Sorghum & -3.15 & 0.11 & 1 & -2.50 & 0.32 & 0 & -6.59 & $0.00 * *$ & 0 \\
\hline 26. & Soybean meal & -4.45 & $0.00 * *$ & 0 & -3.22 & 0.09 & 0 & -8.60 & $0.00 * *$ & 1 \\
\hline 27. & Soybeans & -3.64 & $0.03 *$ & 0 & -2.84 & 0.19 & 0 & -8.40 & $0.00 * *$ & 0 \\
\hline 28. & Sugar & -3.90 & $0.02 *$ & 0 & -3.77 & $0.03 *$ & 1 & -6.49 & $0.00 * *$ & 0 \\
\hline 29. & Tea & -3.97 & $0.02 *$ & 0 & -3.80 & $0.02 *$ & 0 & -8.18 & $0.00 * *$ & 0 \\
\hline 30. & Tin & -1.64 & 0.76 & 0 & -1.64 & 0.76 & 0 & -7.04 & $0.00 * *$ & 0 \\
\hline 31. & Tobacco & -3.04 & 0.13 & 0 & -4.15 & $0.01 * *$ & 2 & -7.58 & $0.00 * *$ & 0 \\
\hline 32. & Wheat & -4.61 & $0.00 * *$ & 1 & -4.00 & $0.01 *$ & 1 & -6.75 & $0.00 * *$ & 1 \\
\hline 33. & Zinc & -3.92 & $0.02 *$ & 1 & -3.69 & $0.03 *$ & 1 & -5.44 & $0.00 * *$ & 0 \\
\hline
\end{tabular}

Notes: 1 . The regression is $y_{t}=\alpha+\beta t+\rho_{1} y_{t-1}+\sum_{i \neq 1} \rho_{i} y_{t-i}+\varepsilon_{t}$ for real commodity prices in levels, logarithms and first differences of the logarithms, with an automatic lag length selection using a Schwarz Information Criterion and maximum lag length set equal to 10 .

2. Double and single asterisks (** and $*$ ) denotes the $p$-value significant at the $1 \%$ and $5 \%$ levels, respectively. 
this annual growth rate is remarkable - the standard deviation of the price changes ranges from 10 percent for tobacco, to as high as 39 percent for sugar (see column 6). Despite ranking lowest in the price fluctuation ladder, the price movement for tobacco is nowhere close to being stable. The average volatility of the annual change in logarithm returns for the 33 commodity prices over the period 1948 to 2006 is more than 21 percent (last row of column 6). Clearly, on a year-to-year basis, commodity prices are highly volatile - and this volatility would be even higher if monthly or daily data were used, as the use of annual rather than monthly data has the effect of smoothing out many of the short-term fluctuations. Some commodities are associated with annual percent changes well over 100 percent (columns 7 and 8), which is obviously huge. Table 2 demonstrates a relatively large dispersion in price changes (column 6) that dominates small secular changes (column 2) for all cases. In other words, the long-term trend for each individual commodity appears to be widely variable, reflecting the large uncertainties associated with these commodities.

In constructing an index of commodity prices, one importance issue to consider is whether equal weighting, instead of a consumption/production weighting system, introduces substantial bias. To investigate this issue, Figure 4 sets out both the weighted GY commodity price index (“GYCPI"), together with an equally-weighted index of this study over the period 1948 to 2003. Both indices are expressed in terms of levels with a common base year for easy comparison. An interesting feature about Figure 4 is the high degree of correlation between the two indices; the correlation is 0.995 over 1948 to 1986 (denoted by unshaded region), and increases slightly to 0.996 when the GYCPI is extended to 2003 (denoted by shaded region) by Pfaffenzeller et al. (2007) (both $p$-values < 0.01). This finding is remarkable since there are qualitative differences in the values of the two price indices, one uses 24 exportweighted commodities and the other 33 equally-weighted primary commodities. Given the high correlation between the two series, the equally-weighted price index employed in this paper seems to support the notion that the trends in broad indices of the prices of primary commodities are not much affected by the different weighting systems used to compute them. 
Table 2

Summary Statistics - Logarithmic Changes in Real Prices of 33 Commodities Annual Observations, 1948-2006

\begin{tabular}{|c|c|c|c|c|c|c|c|c|c|c|}
\hline & & & \multicolumn{3}{|c|}{ Standard Deviation } & \multirow{2}{*}{$\begin{array}{c}\text { Minimum } \\
\text { (7) }\end{array}$} & \multirow[b]{2}{*}{$\begin{array}{c}\text { Maximum } \\
\text { (8) }\end{array}$} & \multirow[b]{2}{*}{$\begin{array}{c}\text { Jarque-Bera } \\
\text { (9) }\end{array}$} & \multirow{2}{*}{$\begin{array}{c}p \text {-value } \\
(10)\end{array}$} \\
\hline & comimiverity & $(2)$ & (3) & $\begin{array}{c}\text { 1948-71 } \\
(4)\end{array}$ & $\begin{array}{c}1972-06 \\
(5)\end{array}$ & $\begin{array}{c}1948-06 \\
(6)\end{array}$ & & & & \\
\hline 1. & Jute & -3.85 & -2.68 & 28.16 & 22.66 & 24.84 & -86.00 & 52.10 & 17.10 & $0.00 * *$ \\
\hline 2. & Groundnut meal & -3.54 & -2.80 & 9.61 & 26.03 & 20.06 & -65.86 & 71.91 & 38.57 & $0.00 * *$ \\
\hline 3. & Palm oil & -3.33 & -1.00 & 13.78 & 28.06 & 23.31 & -68.59 & 49.19 & 0.71 & 0.70 \\
\hline 4. & Copra & -3.28 & 0.47 & 19.59 & 39.62 & 32.95 & -103.63 & 85.74 & 2.64 & 0.27 \\
\hline 5. & Coconut oil & -3.14 & 0.63 & 16.48 & 39.52 & 32.20 & -101.80 & 72.46 & 4.20 & 0.12 \\
\hline 6. & Tea & -3.05 & -4.64 & 12.32 & 18.65 & 16.31 & -59.11 & 49.61 & 24.06 & $0.00 * *$ \\
\hline 7. & Cotton & -2.94 & -3.93 & 12.73 & 20.67 & 17.82 & -40.22 & 47.54 & 4.55 & 0.10 \\
\hline 8. & Rice & -2.83 & -2.93 & 11.88 & 23.85 & 19.86 & -55.97 & 69.68 & 20.57 & $0.00 * *$ \\
\hline 9. & Tobacco & -2.55 & -3.03 & 11.27 & 9.57 & 10.25 & -27.33 & 20.25 & 0.83 & 0.66 \\
\hline 10. & Soybean meal & -2.47 & -2.42 & 15.63 & 23.94 & 20.89 & -60.02 & 79.03 & 33.32 & $0.00 * *$ \\
\hline 11. & Cocoa & -2.39 & -3.94 & 28.02 & 24.68 & 25.84 & -57.26 & 55.40 & 1.85 & 0.40 \\
\hline 12. & Soybeans & -2.35 & -3.84 & 16.44 & 18.07 & 17.30 & -46.23 & 66.79 & 40.00 & $0.00 * *$ \\
\hline 13. & Groundnut oil & -2.29 & -5.33 & 13.97 & 26.11 & 21.96 & -63.80 & 57.46 & 3.11 & 0.21 \\
\hline 14. & Wheat & -2.24 & -2.00 & 6.50 & 18.84 & 15.16 & -31.58 & 66.46 & 103.43 & $0.00 * *$ \\
\hline 15. & Sorghum & -2.16 & -2.18 & 8.97 & 16.18 & 13.68 & -33.65 & 44.69 & 6.70 & $0.04 *$ \\
\hline 16. & Maize & -1.84 & -3.92 & 12.12 & 17.73 & 15.65 & -37.06 & 49.93 & 14.80 & $0.00 * *$ \\
\hline 17. & Oranges & -1.80 & -4.62 & 15.68 & 13.62 & 14.56 & -37.88 & 46.63 & 5.65 & 0.06 \\
\hline 18. & Lead & -1.55 & -0.13 & 20.54 & 25.19 & 23.36 & -43.95 & 51.68 & 0.88 & 0.64 \\
\hline 19. & Sugar & -1.51 & -0.33 & 37.50 & 40.00 & 38.69 & -103.59 & 103.47 & 5.70 & 0.06 \\
\hline
\end{tabular}

(Table continues on the next page.) 
Table 2 (continued)

\section{Summary Statistics - Logarithmic Changes in Real Prices of 33 Commodities}

Annual Observations, 1948-2006

\begin{tabular}{|c|c|c|c|c|c|c|c|c|c|c|}
\hline & & & \multicolumn{3}{|c|}{ Standard Deviation } & \multirow[b]{2}{*}{$\begin{array}{c}\text { Minimum } \\
\text { (7) }\end{array}$} & \multirow[b]{2}{*}{$\begin{array}{c}\text { Maximum } \\
\text { (8) }\end{array}$} & \multirow[b]{2}{*}{$\begin{array}{c}\text { Jarque-Bera } \\
\text { (9) }\end{array}$} & \multirow[b]{2}{*}{$\begin{array}{c}p \text {-value } \\
\text { (10) }\end{array}$} \\
\hline & Comminuty & $(2)$ & (3) & $\begin{array}{c}1948-71 \\
(4)\end{array}$ & $\begin{array}{c}1972-06 \\
(5)\end{array}$ & $\begin{array}{c}1948-06 \\
(6)\end{array}$ & & & & \\
\hline 20. & Tin & -1.26 & -1.02 & 12.85 & 21.64 & 18.55 & -64.58 & 52.71 & 13.32 & $0.00 * *$ \\
\hline 21. & Phosphate rock & -1.10 & -2.37 & 9.05 & 26.87 & 21.51 & -67.72 & 126.88 & $1,180.63$ & $0.00 * *$ \\
\hline 22. & Coffee & -1.06 & -3.96 & 17.48 & 29.91 & 25.55 & -57.45 & 72.62 & 6.89 & $0.03 *$ \\
\hline 23. & Rubber & -0.97 & -3.75 & 29.88 & 21.84 & 25.14 & -47.82 & 84.32 & 11.03 & $0.00 * *$ \\
\hline 24. & Bananas & -0.93 & -0.85 & 8.28 & 13.92 & 11.96 & -36.64 & 31.00 & 6.08 & $0.05 *$ \\
\hline 25. & Bauxite & -0.60 & -1.93 & 9.89 & 13.61 & 11.77 & -16.90 & 51.37 & 289.20 & $0.00 * *$ \\
\hline 26. & Beef & -0.16 & -0.13 & 8.52 & 13.82 & 12.35 & -34.46 & 27.72 & 0.60 & 0.74 \\
\hline 27. & Aluminium & 0.02 & 0.60 & 4.33 & 18.87 & 14.82 & -31.52 & 44.81 & 2.92 & 0.23 \\
\hline 28. & Zinc & 0.36 & 0.63 & 21.57 & 28.03 & 25.56 & -69.58 & 83.16 & 16.24 & $0.00 * *$ \\
\hline 29. & Iron ore & 0.51 & -1.61 & 11.27 & 13.15 & 12.36 & -16.81 & 50.61 & 41.47 & $0.00 * *$ \\
\hline 30. & Logs & 0.57 & -0.22 & 14.42 & 22.74 & 19.72 & -39.86 & 59.14 & 5.57 & 0.06 \\
\hline 31. & Copper & 0.71 & -0.82 & 20.20 & 24.24 & 22.54 & -59.69 & 57.10 & 0.29 & 0.87 \\
\hline 32. & Crude oil & 2.08 & -4.26 & 9.13 & 32.70 & 26.30 & -65.71 & 125.82 & 196.73 & $0.00 * *$ \\
\hline \multirow[t]{2}{*}{33.} & Nickel & 2.21 & 1.84 & 5.15 & 28.16 & 22.00 & -45.90 & 99.90 & 92.66 & $0.00 * *$ \\
\hline & All commodities & -1.47 & -1.90 & 16.45 & 24.13 & 21.38 & -103.63 & 126.88 & & \\
\hline
\end{tabular}

Sources: The 33 commodity annual time series data are taken from Bidarkota and Crucini (2000) and the World Bank, Development Prospects Group primary commodity price databases.

Notes: The underlying data are calculated as nominal commodity prices deflated by the US CPI-U over the period 1948 to 2006 . Entries in columns 2 to 8 are to be divided by 100 . The Jarque-Bera statistic tests the null hypothesis that the distribution conforms to a Gaussian normal distribution. Significance at the $1 \%$ and $5 \%$ confidence levels is indicated by $* *$ and $*$, respectively. 


\section{Figure 4}

Index of Nominal Non-Fuel Commodity Prices - Annual Observations (1948-2003)

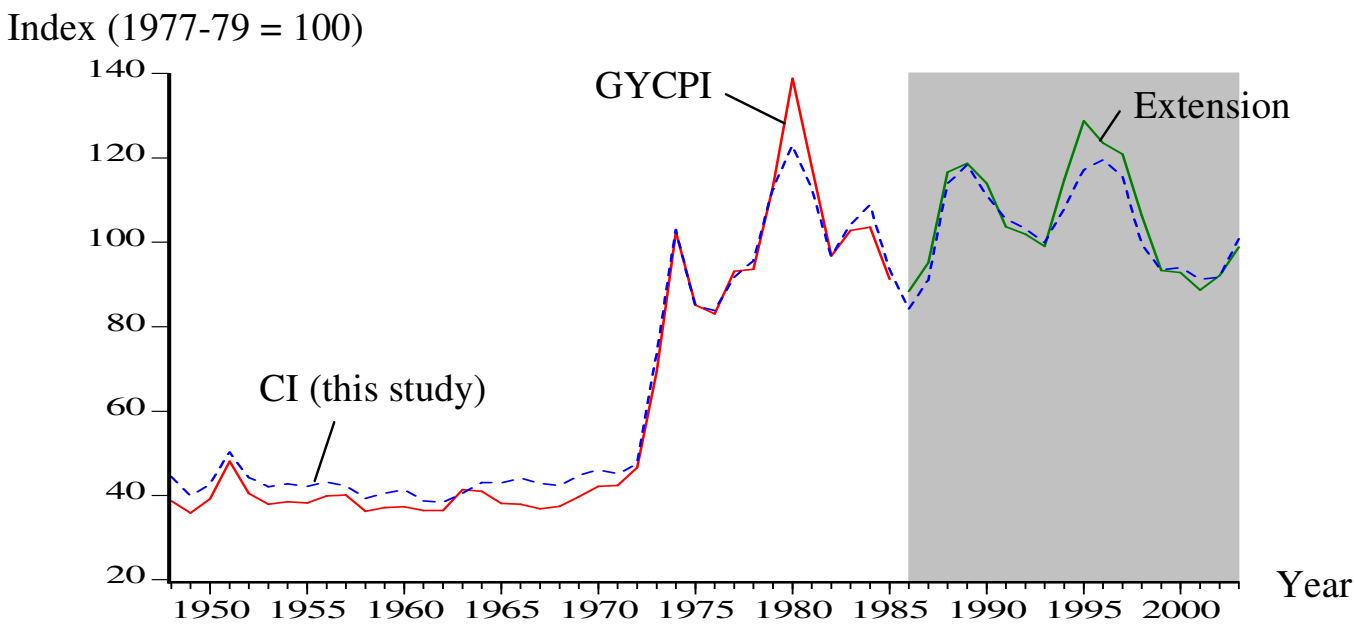

Sources: 1. GYCPI (unshaded region): Grilli and Yang (1988).

2. Extension of GYCPI (shaded region): Pfaffenzeller et al. (2007).

3. CI: Annual time series data are taken from Bidarkota and Crucini (2000) and the World Bank, Development Prospects Group primary commodity price database.

Note: GYCPI and extension of GYCPI are based on 24 internationally-traded non-fuel primary commodities, whereas CI is based on 32 non-fuel commodities. All price series are indexed to their 1977-1979 average.

\section{VOLATILITY OF COMMODITY PRICES}

A striking feature of the behaviour of primary commodities after the collapse of the Bretton Woods fixed exchange rate system has been the high level of price volatility, though this does not imply volatility was particularly low prior to 1971 . Results in columns 4 and 5 of Table 2 reveal that commodity price volatility on average has been higher in the post-1971 period than in the previous 20 years for all except 5 commodities. Overall, price volatility averages about 21 percent from 1948 to 2006. This section sheds light on the nature and sources of this volatility.

\section{$\underline{\text { A Group-Wise Decomposition }}$}

Suppose we group the $n$ commodities into $G$ categories, denoted by $S_{1}, S_{2}, \ldots, S_{G}$, where $G<n$. Each commodity $i$ belongs to one category only, so generally one can write $i \in S_{g}$, and $g=1, \ldots, G$. As $\bar{w}_{i t}=1 / n$ is the weight of commodity $i$ with $\sum_{i=1}^{n} \bar{w}_{i t}=1$, one can define $\bar{W}_{g t}=\sum_{i \in S_{g}} \bar{w}_{i t}=n_{g} / n$ as the weight for group $g$, with $\sum_{g=1}^{G} \bar{W}_{g t}=1$, where $n_{g}$ is the number of goods in group $g$. 
Let the share of $i \in S_{g}$ within its group be $\bar{w}_{i t}^{\prime}=\bar{w}_{i t} / \bar{W}_{g t}=1 / n_{g}$, which satisfies $\sum_{i \in S_{g}} \bar{w}_{i t}^{\prime}=1$. Then $D P_{g t}$, the logarithmic annual return for group $g$ at time $t$, can be written as

$$
D P_{g t}=\sum_{i \in S_{g}} \bar{w}_{i t}^{\prime} D p_{i t}
$$

Given that the overall, or composite, price index was defined earlier as $D P_{t}=\sum_{i=1}^{n} \bar{w}_{i t} D p_{i t}$, it can be written in terms of $D P_{g t}$ as

$$
D P_{t}=\sum_{g=1}^{G} \bar{W}_{g t} D P_{g t},
$$

A comparison of equations (6) and (7) with equation (2) reveals that the model is consistent in aggregation. To clarify this, consider two ways to compute the overall price index $D P_{t}$ :

A. Use the prices to compute the $G$ group indices, $D P_{g t}, g=1, \ldots, G$, according to equation (6) and then take the weighted average of these to gives the overall index $D P_{t}$ according to equation (7).

B. Compute $D P_{t}$ directly from equation (2).

Consistency in aggregation means that these two approaches give exactly the same result for $D P_{t}$.

We shall use $G=3$ groups, food, non-food agricultural and metals commodities. The commodities in each sub-index are given in Table A1.1 of Appendix A1. Note that since crude oil does not belong to any of the sub-groups, in what follows, we use $n=32$ rather than 33 . Rows 1 to 7 of Table 3 show the decomposition of the total index by decades and rows 8 to 9 break the sample period on the basis of exchange rate regimes. Metals is the only group experiencing positive average growth in real prices over the past 58 years. This positive growth is primarily attributed to the strong price increases over the period 2001-2006, when prices grew by more than 10 percent per annum. In contrast, the recent upturns in food and non-food prices have been comparatively small at about one-third of the growth of metals. Table 3 shows that food prices declined in all periods except for 1971-1980 and 2001-2006. Although annual growth rate is positive during these two periods, it is either significantly lower than or approximately the same as the average growth rate $D P_{t}$. The growth rate of 
non-food prices is bounded by that of metals from above, and of food from below. The recent upturn in commodity prices has been large and rapid and is rivalled by only one other period over the last 58 years which is the commodity price boom of the 1970s. Over these two periods, prices for all three groups show a persistent upward trend.

Table 3

Average Annual Growth Rate for Commodity Sub-Categories, 1948-2006

\begin{tabular}{cccccc}
\hline & & \multicolumn{3}{c}{ Sub-Indices } & Total \\
\cline { 3 - 5 } & & Food & Non-Food & Metals & \\
& Period & $D P_{1 t}$ & $D P_{2 t}$ & $D P_{3 t}$ & $D P_{t}$ \\
& $(1)$ & $(2)$ & $(3)$ & $(4)$ & $(5)$ \\
\hline 1. & $1948-1950$ & -2.66 & 4.27 & 1.77 & -0.33 \\
2. & $1951-1960$ & -3.24 & -1.26 & -0.88 & -2.27 \\
3. & $1961-1970$ & -1.07 & -4.81 & 0.22 & -1.29 \\
4. & $1971-1980$ & 1.96 & 2.38 & 2.76 & 2.25 \\
5. & $1981-1990$ & -7.56 & -4.61 & -4.29 & -6.18 \\
6. & $1991-2000$ & -4.47 & -4.73 & -4.38 & -4.52 \\
7. & $2001-2006$ & 3.36 & 2.03 & 10.78 & 5.15 \\
& & & & -0.48 & -1.87 \\
8. & $1948-1971$ & -2.42 & -2.42 & 0.39 & -1.34 \\
9. & $1972-2006$ & -2.10 & -1.54 & & \\
10. & & & & & \\
\hline
\end{tabular}

Note: All entries are to be divided by 100 and are simple averages over the corresponding periods.

Equation (6) is a weighted first-order moment of $D p_{1 t}, \ldots, D p_{n_{g} t}$. The corresponding second-order moment is

$$
\Pi_{g t}=\sum_{i \in S_{g}} \bar{w}_{i t}^{\prime}\left(D p_{i t}-D P_{g t}\right)^{2},
$$

which measures the dispersion across commodities within the group. Table 4 gives $\Pi_{g t}$ for the period 1948 to 2006 . Over the fixed exchange rate regime, prices of metals tended to be reasonably tranquil with a standard deviation of $\sqrt{\Pi_{3}}=\sqrt{0.0137}$, or about 12 percent. In contrast, metals price volatility increased substantially after the collapse of the Bretton Woods fixed exchange rate system. On average, the volatility of food prices also increased substantially from the fixed to managed- 
floating exchange rate systems, but non-food remained fairly stable. This finding is consistent with earlier work by Deaton and Laroque (1992) and agrees with previous research indicating exchange-rate movements as a major cause of commodity price instability (see, for example, Sjaastad and Scacciavillani 1996). Finally, the last row of Table 4 shows that on average over the whole period, there is greater price dispersion for food as a group, followed by non-food and metals. Overall, Table 4 shows that price volatility appears to be persistent over time.

One other feature of Table 4 is worthy of note. Column 5 gives the weighted average of the within-group variances. Interestingly, this value is always lower but close to the total variance shown in the last column. Looking at the last entries of the last two columns of the table, the differences is on average $3.46-3.13=33$ basis point. What is the reason for this discrepancy between the two values? The answer is provided in the next sub-section.

Table 4

Average Price Variability for Commodities, 1948-2006

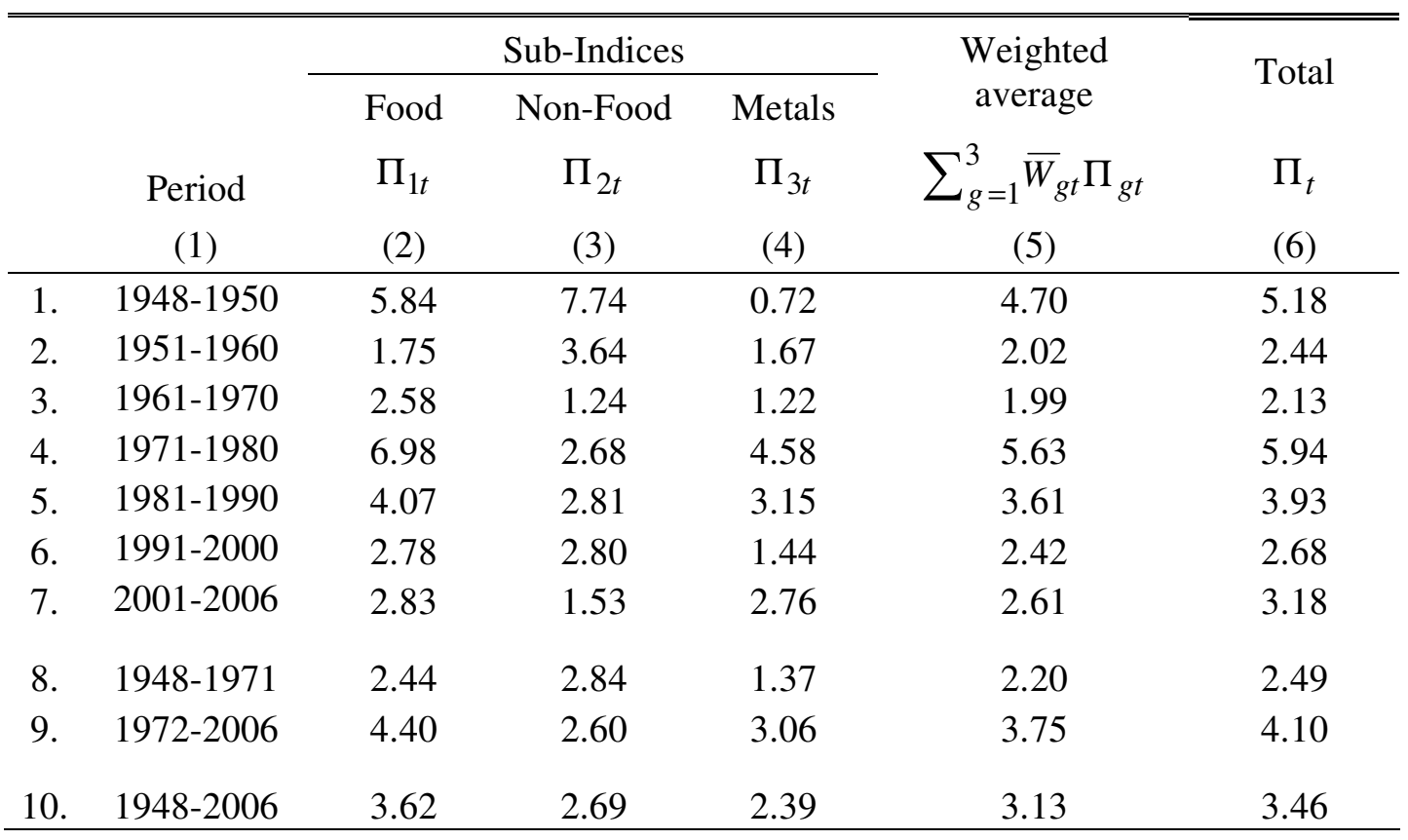

Notes: 1. All entries are to be divided by 100 and are simple averages over the corresponding periods.

2. The total variance $\Pi_{t}$ shown in the last column is defined as $\sum_{i=1}^{32} \bar{w}_{i t}\left(D p_{i t}-D P_{t}\right)^{2}$. 


\section{Within- and Between-Group Volatility}

As demonstrated earlier, the cross-sectional standard deviation of world commodity prices at time $t$ is given by equation (3), $\Pi_{t}=\sum_{i=1}^{n} \bar{w}_{i t}\left(D p_{i t}-D P_{t}\right)^{2}$. In the context of commodity sub-groups, some of the cross-sectional price dispersion are potentially the consequence of within-group variations while the remaining variations can be attributed to between-group components. This sub-section analyses the importance of each component by means of a simple decomposition. ${ }^{8}$ Consider the identity $(1 / n) \sum_{i=1}^{n}\left(x_{i}-\bar{x}\right)^{2}=(1 / n) \sum_{i=1}^{n} x_{i}^{2}-\bar{x}^{2}$. One can then use a weighted version of this identity to express the cross-sectional price variance of equation (3) as

$$
\Pi_{t}=\sum_{i=1}^{n} \bar{w}_{i t} D p_{i t}^{2}-D P_{t}^{2}
$$

while the cross-sectional variance of group $g$, equation (8), is $\Pi_{g t}=\sum_{i \in S_{g}} \bar{w}_{i t}^{\prime} D p_{i t}^{2}-D P_{g t}^{2}$. Take the weighted average of the $G$ group variances to obtain

$$
\sum_{g=1}^{G} \bar{W}_{g t} \Pi_{g t}=\sum_{g=1}^{G} \bar{W}_{g t}\left(\sum_{i \in S_{g}} \bar{w}_{i t}^{\prime} D p_{i t}^{2}-D P_{g t}^{2}\right)=\sum_{i=1}^{n} \bar{w}_{i t} D p_{i t}^{2}-\sum_{g=1}^{G} \bar{W}_{g t} D P_{g t}^{2} .
$$

Rearrange and bring the term $\sum_{i=1}^{n} \bar{w}_{i t} D p_{i t}^{2}$ to the left-hand side so that

$$
\sum_{i=1}^{n} \bar{w}_{i t} D p_{i t}^{2}=\sum_{g=1}^{G} \bar{W}_{g t} \Pi_{g t}+\sum_{g=1}^{G} \bar{W}_{g t} D P_{g t}^{2} .
$$

Substituting equation (9) into equation ( $3^{\prime}$ ), the variance for $n$ commodities can be written as the sum of the weighted average of the variances for the $G$ sub-groups and the variance between the sub-groups:

$$
\Pi_{t}=\sum_{g=1}^{G} \bar{W}_{g t} \Pi_{g t}+\sum_{g=1}^{G} \bar{W}_{g t}\left(D P_{g t}-D P_{t}\right)^{2} .
$$

Equation (10) provides a simple and elegant decomposition. The total price volatility can be decomposed into two components: The first term is a weighted average of $\Pi_{1 t}, \ldots, \Pi_{G t}$, the variances of the $G$ groups, corresponding to a "within-group"

8 The decomposition analysis used in this paper is based on that of Chan and Clements (2007). They investigate the cross-country distribution of the world economic growth, and the components of growth volatility. 
component. The second term, $\sum_{g=1}^{G} \bar{W}_{g t}\left(D P_{g t}-D P_{t}\right)^{2}$, is a "between-group" component. This thus provides the answer to the question raised at the end of the previous sub-section regarding the discrepancy between the total variance and the weighted average of the variances over the $G$ sub-groups. Since the difference between the two values is small in Table 4, we see that the between-group component is not a dominant factor affecting the overall variance. In other words, within each commodity group on average, there is more price volatility relative to that between groups. The above also shows that $\Pi_{t}$ always exceeds $\sum_{g=1}^{G} \bar{W}_{g t} \Pi_{g t}$ since the between-group component is always a positive value. This can be confirmed by a comparison of columns 5 and 6 of Table 4 .

Table 5 demonstrates that the total price variance can be decomposed into within- and between-group components, and that the discrepancy observed earlier in Table 4 can be explained by the between-group component, given in columns 6 to 9 of Table 5. The within-group component (column 5) first decreases over time until the breakdown of the Bretton Woods fixed exchange rate system. This is where the within-group component rises almost three-fold compared to the previous decade and reaches a record high with average annual growth of 5.63 percent, but thereafter decreases substantially. The between-group component shows a similar pattern over time except that the highest price variation is recorded after the turn of the century. This finding supports the view that relative prices of primary commodities exhibit greater volatility under flexible relative to fixed exchange rate regimes. On average, real price variability under the floating exchange period is roughly 30 percent larger than under the fixed exchange period (that is, $\sqrt{4.10 / 2.49} \approx 1.3$ ). The volatility of commodity price returns, $\sqrt{\Pi_{t}}$, is 15.8 percent over the pre-1972 period, and grew substantially higher post-1972 to 20.2 percent per year.

Interestingly, in the within-group components, food (column 2) is the dominant source of dispersion. Such a result may not come as a surprise since the commodities in this group alone account for nearly 60 percent of the share of the overall price index. In addition, the effect of the between-group component is significantly smaller than its within-group counterparts in overall price volatility. In all cases, the betweengroup component accounts for less than 20 percent of price variability, whereas the within-group component accounts for the remaining 80 percent. 
Table 5

Decomposition of Price Volatility into Within- and Between-Group Components, 1948-2006

\begin{tabular}{|c|c|c|c|c|c|c|c|c|c|}
\hline \multirow{4}{*}{$\begin{array}{c}\text { Period } \\
(1)\end{array}$} & \multicolumn{4}{|c|}{ Within-Group Components } & \multicolumn{4}{|c|}{ Between-Group Components } & \multirow{3}{*}{$\begin{array}{c}\text { Total } \\
\text { Variance }\end{array}$} \\
\hline & Food & Non-Food & Metals & Sum & Food & Non-Food & Metals & Sum & \\
\hline & $\bar{W}_{1} \Pi_{1}$ & $\bar{W}_{2} \Pi_{2}$ & $\bar{W}_{3} \Pi_{3}$ & $\sum_{g=1}^{3} \bar{W}_{g} \Pi_{g}$ & $\bar{W}_{1}\left(D P_{1}-D P\right)^{2}$ & $\bar{W}_{2}\left(D P_{2}-D P\right)^{2}$ & $\bar{W}_{3}\left(D P_{3}-D P\right)^{2}$ & $\sum_{g=1}^{3} \bar{W}_{g}\left(D P_{g}-D P\right)^{2}$ & \\
\hline & $(2)$ & $(3)$ & $(4)$ & $(5)$ & (6) & $(7)$ & $(8)$ & $(9)$ & $(10)=(5)+(9)$ \\
\hline 1. $1948-1950$ & 3.28 & 1.21 & 0.20 & 4.70 & 0.11 & 0.07 & 0.30 & 0.48 & 5.18 \\
\hline 2. $1951-1960$ & 0.98 & 0.57 & 0.47 & 2.02 & 0.09 & 0.17 & 0.16 & 0.42 & 2.44 \\
\hline 3. $1961-1970$ & 1.45 & 0.19 & 0.34 & 1.99 & 0.04 & 0.05 & 0.06 & 0.15 & 2.13 \\
\hline 4. $1971-1980$ & 3.92 & 0.42 & 1.29 & 5.63 & 0.08 & 0.08 & 0.15 & 0.31 & 5.94 \\
\hline 5. $1981-1990$ & 2.29 & 0.44 & 0.89 & 3.61 & 0.07 & 0.14 & 0.10 & 0.32 & 3.93 \\
\hline 6. $1991-2000$ & 1.59 & 0.44 & 0.39 & 2.42 & 0.08 & 0.05 & 0.14 & 0.27 & 2.68 \\
\hline 7. 2001-2006 & 1.62 & 0.25 & 0.75 & 2.61 & 0.15 & 0.04 & 0.38 & 0.57 & 3.18 \\
\hline 8. $1948-1971$ & 1.37 & 0.44 & 0.38 & 2.20 & 0.07 & 0.10 & 0.12 & 0.29 & 2.49 \\
\hline 9. $1972-2006$ & 2.49 & 0.41 & 0.85 & 3.75 & 0.09 & 0.08 & 0.18 & 0.35 & 4.10 \\
\hline 10 1948-2006 & 2.04 & 0.42 & 0.67 & 3.13 & 0.08 & 0.09 & 0.15 & 0.33 & 3.46 \\
\hline
\end{tabular}

Note: All entries are to be divided by 100 and are simple averages over the corresponding periods. 
More Decompositions - A CAPM Approach

Consider the change in the price of commodity $i$ relative to the mean, $D p_{i t}-D P_{t}$. It is natural to consider the weighted deviation $\bar{w}_{i t}\left(D p_{i t}-D P_{t}\right)$, which satisfies $\sum_{i} \bar{w}_{i t}\left(D p_{i t}-D P_{t}\right)=0$. Suppose this weighted deviation is a linear function of the price index, $D P_{t}$ :

$$
\bar{w}_{i t}\left(D p_{i t}-D P_{t}\right)=\alpha_{i}^{\prime}+\beta_{i}^{\prime} D P_{t}+\varepsilon_{i t}^{\prime},
$$

where $\alpha_{i}^{\prime}$ is the intercept, $\beta_{i}^{\prime}$ is the slope coefficient and $\varepsilon_{i t}^{\prime}$ is the error term reflecting omitted factors. As $\sum_{i=1}^{n} \bar{w}_{i t}\left(D p_{i t}-D P_{t}\right)=0$, each term on the right-hand side of equation (11) has a zero sum over the $n$ commodities, which implies

$$
\sum_{i=1}^{n} \alpha_{i}^{\prime}=\sum_{i=1}^{n} \beta_{i}^{\prime}=\sum_{i=1}^{n} \varepsilon_{i t}^{\prime}=0 .
$$

Now assume individual commodities are grouped into their respective categories: food, non-food and metals. Then if we add the left-hand side of equation (11) over $i \in S_{g}$ we obtain

$$
\sum_{i \in S_{g}} \bar{w}_{i t}\left(D p_{i t}-D P_{t}\right)=\sum_{i \in S_{g}} \bar{w}_{i t} D p_{i t}-\sum_{i \in S_{g}} \bar{w}_{i t} D P_{t}=\bar{W}_{g t}\left(D P_{g t}-D P_{t}\right),
$$

where $\bar{W}_{g t}=\sum_{i \in S_{g}} \bar{w}_{i t}$ is the share for group $g$, as before. Similarly, the right-hand side of equation (11) can be aggregated as $\sum_{i \in S_{g}} \alpha_{i}^{\prime}+\sum_{i \in S_{g}} \beta_{i}^{\prime} D P+\sum_{i \in S_{g}} \varepsilon_{i t}^{\prime}=A_{g}+B_{g} D P_{t}+E_{g t} \quad, \quad$ where $A_{g}=\sum_{i \in S_{g}} \alpha_{i}^{\prime}$, $B_{g}=\sum_{i \in S_{g}} \beta_{i}^{\prime}$, and $E_{g t}=\sum_{i \in S_{g}} \varepsilon_{i t}^{\prime}$. Therefore, the group-wise version of equation (11) for group $g$ takes on the form

$$
\bar{W}_{g t}\left(D P_{g t}-D P_{t}\right)=A_{g}+B_{g} D P_{t}+E_{g t} .
$$

Comparing equation (11) with $\left(11^{\prime}\right)$, we see that the latter is just an "uppercase" version of the former, so that the model is consistent in aggregation. As shown from equation (7), $D P_{t}$ is the weighted average of all $D P_{g t}$, indicating that the summation of the weighted deviation of growth in group $g$ from the average growth rate is zero, such that $\sum_{g=1}^{G} \bar{W}_{g t}\left(D P_{g t}-D P_{t}\right)=0$. As the left-hand side of equation 
$\left(11^{\prime}\right)$ when summed over the $g$ sub-groups is zero, it follows that the right-hand side of equation (11') satisfies

$$
\sum_{g=1}^{G} A_{g}=\sum_{g=1}^{G} B_{g}=\sum_{g=1}^{G} E_{g t}=0 .
$$

To interpret equation $\left(11^{\prime}\right)$, divide by $\bar{W}_{g t}$ and add $D P_{t}$ to the both sides, to obtain the growth of group $g$ as

$$
D P_{g t}=\frac{A_{g}}{\bar{W}_{g t}}+\left(1+\frac{B_{g}}{\bar{W}_{g t}}\right) D P_{t}+\frac{E_{g t}}{\bar{W}_{g t}} .
$$

Equation (14) is exactly the same as the CAPM equation mentioned earlier in Section 3 but now refers to groups of commodities rather than individual commodities. Therefore, the first term on the right of equation (14) is the intercept that captures the influence of idiosyncratic factors independent of common factors unique to each group $g$. The second term is the slope coefficient, representing the return to group $g$ that is attributed by the systematic factors common to all commodity groups. Finally, the last term, $E_{g t} / \bar{W}_{g t}$, denotes the remaining risk factors not captured by systematic or idiosyncratic risk. The term $\left(1+B_{g} / \bar{W}_{g t}\right)$ also measures the elasticity of $P_{g t}$ with respect to $P_{t}$. In other words, if the growth rate of the prices of group $g$ coincides with mean growth rate $D P_{t}$, the elasticity is unity, so that $B_{g} / \bar{W}_{g t}$, or simply $B_{g}$, is zero. The term $B_{g} / \bar{W}_{g t}$ is the beta coefficient for group $g$. The coefficient, $B_{g}$, can be positive or negative depending on whether group $g$ grows faster or slower relative to the mean growth rate.

Table 6 presents the OLS estimates of equation (11') for $G=3$ sub-indices over the period 1948 to 2006 . The intercept $A_{g}$ represents the impact of overall growth for each group $g$ attributed by idiosyncratic risk factors and is found to be insignificantly different from zero for all three sub-groups. This result is consistent with the portfolio theory: when combining an individual commodity into its respective category, such diversity helps to eliminate the effects of highly idiosyncratic events which are likely to have large implications for the individual commodity markets. In other words, when aggregated into sub-indices, the overall risk is reduced without sacrificing any returns. In such cases, systematic economic forces have become the 
major source of price instability influencing the world commodity markets. The elasticity of growth (column 7) for the food subgroup is 1.04-only slightly higher than its metals counterpart, which has an elasticity of 1.02. Hypothesis testing reveals that both elasticities are statistically insignificantly different from unity (see columns 4 and 5). On the other hand, the non-food elasticity of growth is shown to be substantially lower than those of the food and metals sub-groups, being equal to 0.82 over the sample period.

Table 6

Price Growth Decomposition into Systematic and Idiosyncratic Risk, 1948-2006

\begin{tabular}{|c|c|c|c|c|c|c|}
\hline \multirow[b]{2}{*}{$\begin{array}{c}\text { Sub-Index } \\
\text { (1) }\end{array}$} & \multicolumn{2}{|c|}{ Intercept $A_{g}$} & \multicolumn{2}{|c|}{ Slope $B_{g}$} & \multirow{2}{*}{$\begin{array}{c}A_{g} / \bar{W}_{g t} \\
(6)\end{array}$} & \multirow{2}{*}{$\begin{array}{c}\text { Elasticity } \\
\begin{array}{c}1+B_{g} / \bar{W}_{g t} \\
(7)\end{array}\end{array}$} \\
\hline & $\begin{array}{c}\text { Coefficient } \\
\text { (2) }\end{array}$ & $\begin{array}{l}\text { SE } \\
\text { (3) }\end{array}$ & $\begin{array}{c}\text { Coefficient } \\
\text { (4) }\end{array}$ & $\begin{array}{l}\text { SE } \\
(5) \\
\end{array}$ & & \\
\hline 1. Food & -0.29 & 0.32 & 0.02 & 0.03 & -0.51 & 1.04 \\
\hline 2. Non-food & -0.11 & 0.18 & -0.03 & 0.02 & -0.69 & 0.82 \\
\hline 3. Metals & 0.40 & 0.30 & 0.01 & 0.03 & 1.41 & 1.02 \\
\hline Sum & 0.00 & & 0.00 & & & \\
\hline
\end{tabular}

Note: SE denotes standard error.

\section{ON THE RELATION BETWEEN PRICES AND VOLATILITY}

The proposition that the average rate of change of prices has an effect on the variability of relative price changes has given rise to an extensive empirical literature. Vining and Elwertowski (1976) conclude that there is a positive relationship between the variance of relative prices and the general price change, although the authors fail to provide any explanations of their result. In contrast, Parks' (1978) seminar paper considers a multimarket model of prices that he applies to the US over the periods 1930-1941 and 1948-1975. His results show a significant association between the variance of relative prices and the rate of inflation. However, it must be emphasised that Parks' findings are controversial as several authors subsequently argued that the relationship between price variability and inflation is only a by-product of the oil shock in $1974 .{ }^{9}$ This section considers if the variability of commodity prices is related to their overall average change.

9 See, for example, Bomberger and Makinen (1993) and Jaramillo (1999). 
There can be little doubt that the collapse of Bretton Woods fixed exchange rate system has contributed substantially to the variability of the prices of internationallytraded primary commodities. Panel A of Figure 5 shows the plot of annual volatility of 33 commodity price series, $\sqrt{\Pi_{t}}$, against time. Interestingly, price volatility has a tendency to revert back to the mean over time. This finding is consistent with Pindyck (2001) who examines price volatility at the individual commodity level. By using daily and weekly data for the three commodities that make up the petroleum complex, he finds rapid mean reverting of price volatilities for crude oil, heating oil and gasoline over the period 1984 to 2001.

Figure 5

Annual Volatility and Composite Price Index, 33 Commodity Prices, 1948-2006

\section{A. Cross-Sectional Volatility}

$$
\sqrt{\Pi_{t}}
$$

(\% p.a.)

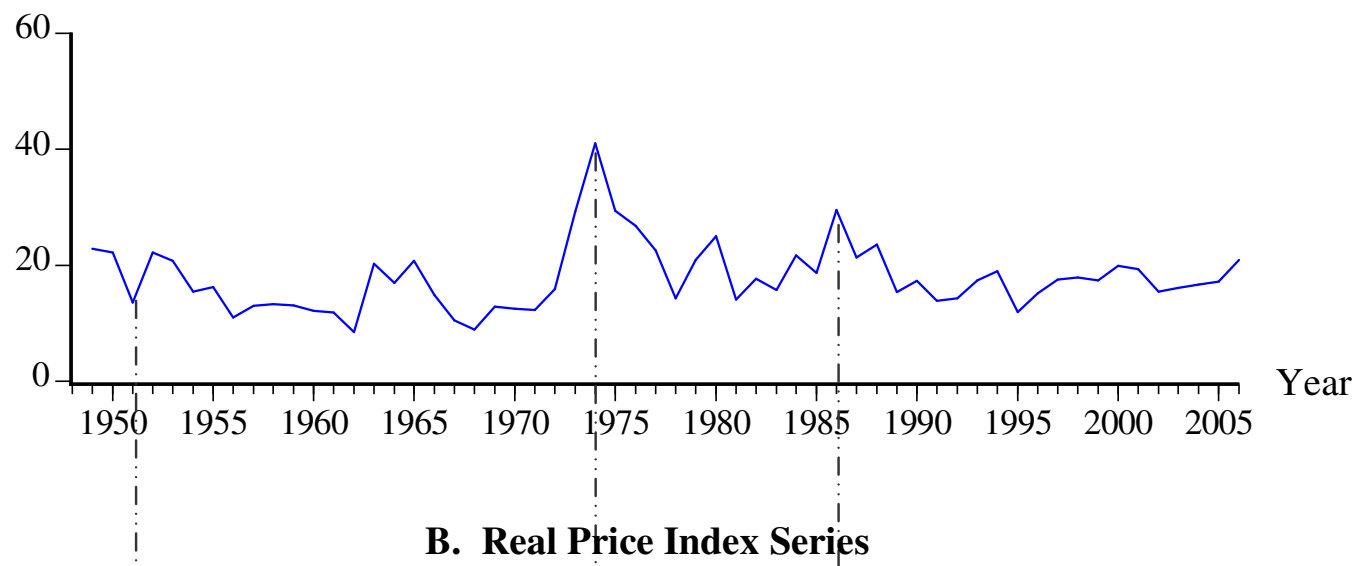

Index $(1977-79=100)$

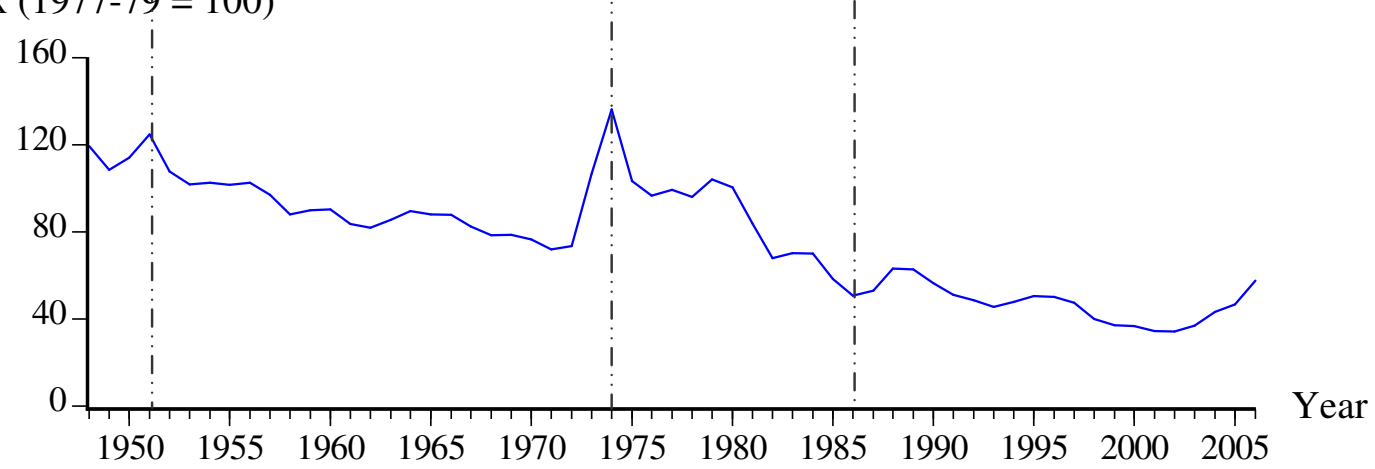

Notes: 1. Volatility is based on cross-sectional standard deviation of 33 commodity price series. 2. Real price is obtained by deflating nominal price by US CPI-U. 
There is evidence of lower price volatility prior to the 1970s. Generally, volatility fluctuates up and down quite sporadically and there appears to be a sudden rise in 1974. What has caused this jump in volatility? Panel B above shows real price index for 33 commodities, which provide some indications about the rapid change in volatility level shown in Panel A. The sharp rise in the price index following the effects of the Arab oil embargo in 1973 seems to be the cause of the spike in volatility. As illustrated by the gray dotted line, the peak in the level of volatility coincides well with the peak in the overall price index. Furthermore, the spikes observed in Panel A in year 1951 and 1986 seem to perfectly match either a peak or trough in the corresponding price index in Panel B. This thus provides some preliminary evidence regarding to interrelationship between volatility and the level of commodity prices.

Figure 6 shows the plot of annual volatility together with the log-changes of the price index (fuel included) from 1948 to 2006 . It can be seen that when volatility is relatively low over the period 1954 to 1972 , the price index is mostly below its 58year average and corresponds to modest price changes that tend to fall in the band \pm 10 percent. Throughout the remaining period where the rates of change in volatility are much higher, the index of price changes itself tends to be more volatile.

\section{Figure 6}

\section{Relationship between Volatility and Relative Change in Price Index, 1948-2006}

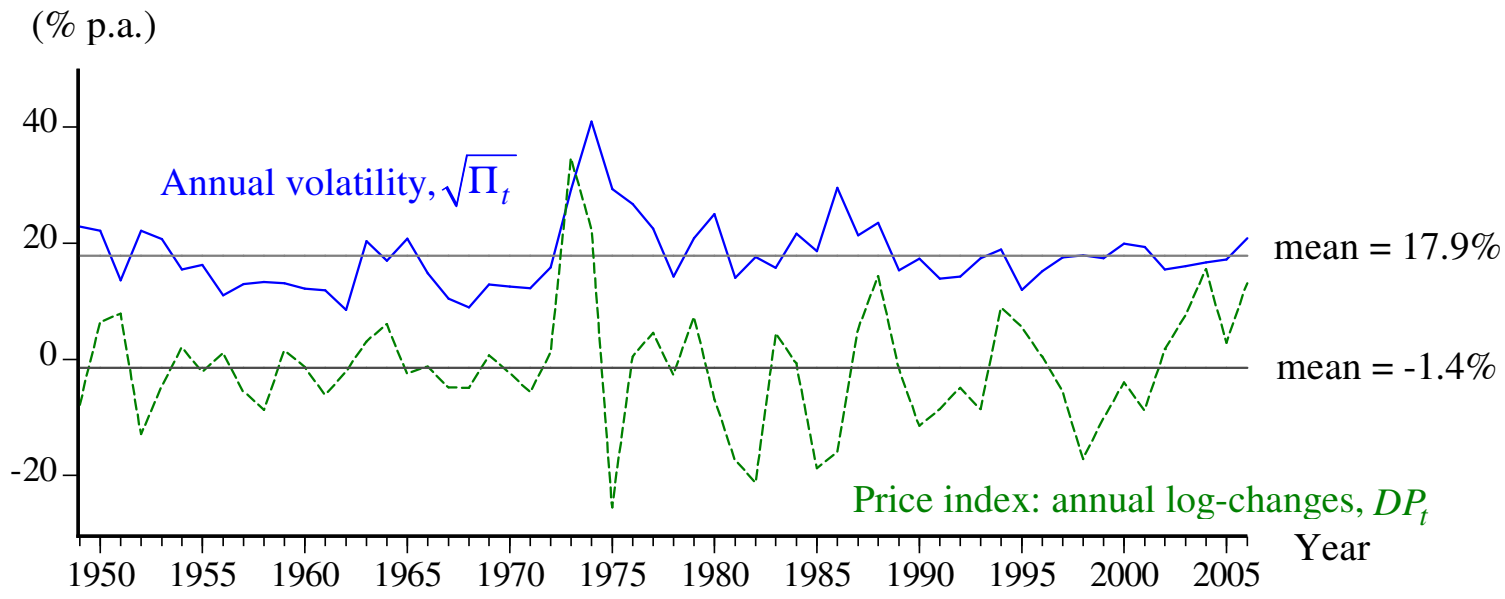

Next, Figure 7 provides the same information in the form of a scatter plot of volatility against the absolute value of $D P_{t}$. Only four out of the 58 points lie below the 45-degree line, suggesting that volatility is higher than average price changes. 
This observed difference between the behaviour of commodity price variance and change in relative prices was noted previously (see, for example, Cashin and McDermott 2002; Deaton 1999). The four points that lie below the 45-degree line correspond to $1973,1981,1982$ and 1985 . In 1973 there is a positive price change of 35 percent. In contrast, world commodities experienced a fall in prices for the other three years, -17 percent in 1981, -21 percent in 1982 and -19 percent in 1985. The most important question is: does the conclusion drawn by Parks (1978) regarding to the relationship between inflation rate and variance of relative prices changes still survive? Figure 7 indicates a positive relationship between the two variables with a correlation coefficient of 0.55 ; this decreases slightly to 0.49 when the 1974 observation is excluded. Both these estimates are statistically significant at the 1 percent level.

A summary of this material is as follows. There is a strong and positive relationship between the variance of relative price changes and the average rate of price changes. In addition, this relationship remains strong even after removing data from 1974, when the price of oil suffered severe shocks. Such results are inconsistent with the evidence from previous studies.

\section{Figure 7}

\section{Scatter Plot of Volatility Against Absolute Log-Changes in Relative Price Index,}

1948-2006

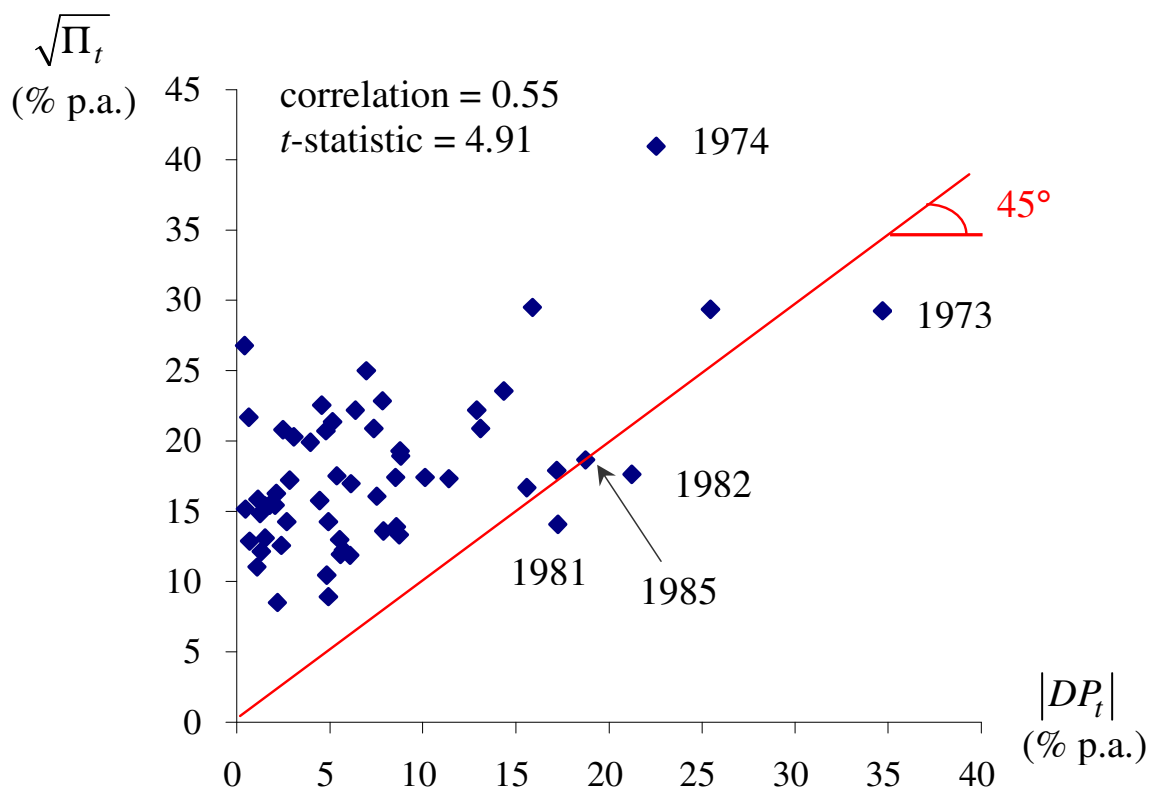




\section{GLOBAL VERSUS IDIOSYNCRATIC RISK}

This section splits fluctuations in commodity prices into global and idiosyncratic parts. Variations in commodity returns may be the result of common movements in macroeconomic variables that affect the demand for or the supply of broad sets of commodities, as well as commodity-specific factors that are unique to each commodity. Conceptually, the former component cannot be diversified away by combining with other commodities in a portfolio, whereas the latter can. A better understanding of these two components provides some indication of the gain from export diversification.

To differentiate global risk from idiosyncratic risk, equation (5) is estimated. The dependent variable is returns, while the independent variable is the return on an equal-weighted commodity price index (fuel included). The results are given in Table 7. Commodities are divided into their respective categories and ranked in ascending order according to the estimated slope coefficient, $\beta_{i}$, for $i=1, \ldots, 33$ (column 4). All 33 commodities have estimated intercept terms that are statistically insignificant. The slope coefficient $\beta_{i}$ can be used to approximate the overall volatility of an individual commodity's return relative to the world commodity market returns.

According to the table, copra has the largest slope coefficient of 2.36, indicating the price of copra increases by more than 2 percent when the index increases by 1 percent. In other words, copra is very sensitive to worldwide macroeconomic factors. Conversely, iron ore has an insignificant $\beta$ of 0.01 , implying the price of iron ore is almost completely insensitive to systematic global factors. One explanation for such a phenomenon is that iron ore is not traded on the London Metal Exchange unlike the majority of base metals commodities. Rather, the iron ore prices used in this paper are contract prices negotiated annually and agreed upon between iron ore producers in Brazil and steel manufacturers in Europe. By averaging across all commodities, the mean values for $\beta_{i}$ and $\alpha_{i}$ equal one and zero, respectively, as anticipated.

Columns 11 and 12 of Table 7 contain $R^{2}$ and $1-R^{2}$ values for each of the regressions. What stands out is the importance of global risk for the relative prices of coconut oil $\left(R^{2}=50 \%\right)$ and copra $\left(R^{2}=54 \%\right)$. More notably, they are the only two commodities whose global macroeconomic risk factor is greater than 50 percent 
Table 7

Time-Series Regressions for Annual Growth Rate of 33 Commodities, 1948-2006

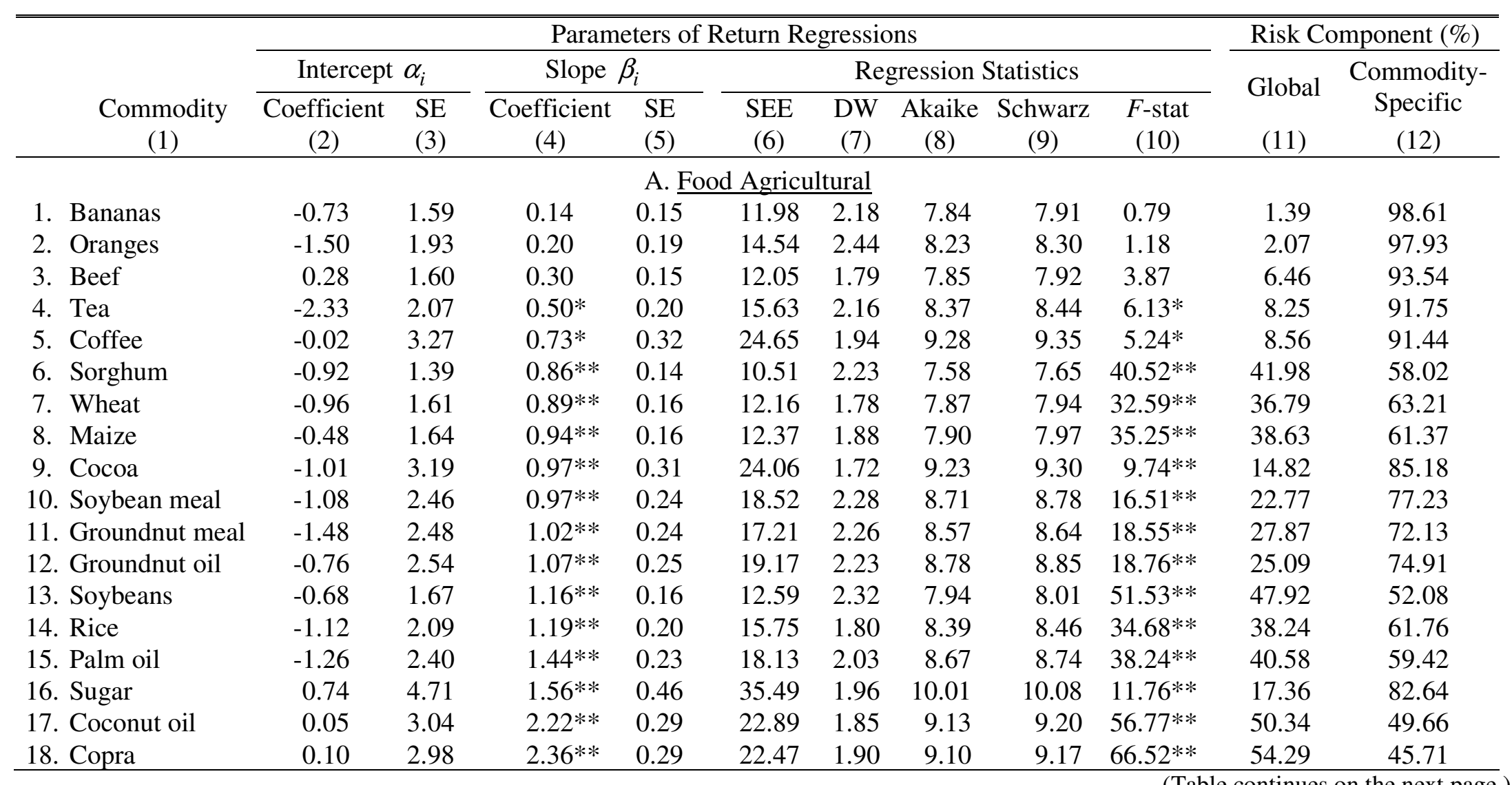


Table 7 (continued)

Time-Series Regressions for Annual Growth Rate of 33 Commodities, 1948-2006

\begin{tabular}{|c|c|c|c|c|c|c|c|c|c|c|c|}
\hline \multirow[b]{3}{*}{$\begin{array}{c}\text { Commodity } \\
\text { (1) }\end{array}$} & \multicolumn{9}{|c|}{ Parameters of Return Regressions } & \multicolumn{2}{|c|}{ " Risk Component (\%) } \\
\hline & \multicolumn{2}{|c|}{ Intercept $\alpha_{i}$} & \multicolumn{2}{|c|}{ Slope $\beta_{i}$} & \multicolumn{5}{|c|}{ Regression Statistics } & \multirow{2}{*}{$\begin{array}{c}\text { Global } \\
\text { (11) }\end{array}$} & \multirow{2}{*}{$\begin{array}{c}\text { Commodity } \\
\text { Specific } \\
(12)\end{array}$} \\
\hline & $\begin{array}{c}\text { Coefficient } \\
\text { (2) }\end{array}$ & $\begin{array}{l}\text { SE } \\
(3) \\
\end{array}$ & $\begin{array}{c}\text { Coefficient } \\
(4)\end{array}$ & $\begin{array}{l}\text { SE } \\
(5) \\
\end{array}$ & $\begin{array}{l}\text { SEE } \\
(6)\end{array}$ & $\begin{array}{l}\text { DW } \\
(7)\end{array}$ & $\begin{array}{c}\text { Akaike } \\
(8)\end{array}$ & $\begin{array}{c}\text { Schwarz } \\
(9)\end{array}$ & $\begin{array}{c}F \text {-stat } \\
(10)\end{array}$ & & \\
\hline \multicolumn{12}{|c|}{ B. Non-food Agricultural } \\
\hline 1. Tobacco & -2.44 & 1.37 & 0.08 & 0.13 & 10.31 & 2.06 & 7.54 & 7.61 & 0.38 & 0.68 & 99.32 \\
\hline 2. Jute & -2.59 & 3.25 & $0.71 *$ & 0.31 & 23.96 & 2.32 & 9.23 & 9.30 & $5.14^{*}$ & 8.69 & 91.31 \\
\hline 4. Cotton & -1.51 & 1.95 & $1.00 * *$ & 0.19 & 14.68 & 2.47 & 8.25 & 8.32 & $27.91 * *$ & 33.26 & 66.74 \\
\hline 5. Rubber & 1.35 & 2.52 & $1.62 * *$ & 0.24 & 19.01 & 1.94 & 8.76 & 8.83 & $43.66 * *$ & 43.81 & 56.19 \\
\hline \multicolumn{12}{|c|}{ C. Base Metals } \\
\hline 1. Iron ore & 0.53 & 1.65 & 0.01 & 0.16 & 12.47 & 1.19 & 7.92 & 7.99 & 0.00 & 0.01 & 99.99 \\
\hline 2. Bauxite & -0.06 & 1.72 & 0.29 & 0.16 & 11.49 & 2.20 & 7.76 & 7.84 & 3.19 & 6.75 & 93.25 \\
\hline 3. Phosphate rock & -0.16 & 2.73 & $0.65 *$ & 0.27 & 20.61 & 1.78 & 8.92 & 8.99 & $6.06 *$ & 9.77 & 90.23 \\
\hline 4. Aluminium & 1.06 & 1.71 & $0.73 * *$ & 0.17 & 12.89 & 1.91 & 7.99 & 8.06 & $19.32 * *$ & 25.65 & 74.35 \\
\hline 6. Tin & 0.50 & 1.82 & $1.23 * *$ & 0.18 & 13.70 & 2.34 & 8.11 & 8.18 & $48.45 * *$ & 46.39 & 53.61 \\
\hline 7. Copper & 2.87 & 2.19 & $1.50 * *$ & 0.21 & 16.52 & 1.63 & 8.48 & 8.55 & $50.03 * *$ & 47.19 & 52.81 \\
\hline 8. Lead & 0.61 & 2.33 & $1.51 * *$ & 0.23 & 17.61 & 2.25 & 8.61 & 8.68 & $44.27 * *$ & 44.15 & 55.85 \\
\hline 9. Zinc & 2.87 & 2.43 & $1.74 * *$ & 0.24 & 18.33 & 1.52 & 8.69 & 8.76 & $54.75 * *$ & & 50.56 \\
\hline 1. Crude oil & 3.94 & 3.03 & $1.30 * *$ & 0.29 & D. $\frac{\mathrm{Oil}}{22.85}$ & 1.98 & 9.13 & 9.20 & $19.53 * *$ & 25.86 & 74.14 \\
\hline Mean & -0.02 & & 1.00 & & & & & & & 26.43 & 73.57 \\
\hline
\end{tabular}

Notes: 1. Double and single asterisks $(* *$ and $*)$ denote estimated coefficients significantly different from zero at the $1 \%$ and $5 \%$ levels, respectively.

2. $\mathrm{SE}=$ standard error. $\mathrm{SEE}=$ standard error of the regression. $\mathrm{DW}=$ Durbin-Watson statistic. 
of the total risk. Generally, the $R^{2}$ values are low, with most of the price variance explained by risk factors unique to each commodity. The average $R^{2}$ across the 33 commodities is approximately 26 percent. Commodities whose idiosyncratic risk accounts for almost all the variations in annual returns over 1948 to 2006 include banana, iron ore, oranges and tobacco.

An obvious caveat to the above results relates to the sample period, 1948 to 2006 which contains the transition from a period of fixed to floating exchange rate. As Deaton and Laroque (1992) and Cuddington and Liang (2003) persuasively demonstrated, primary commodity prices tend to be more volatile under floating than fixed exchange rates, and the econometric implications of merging data from the two exchange rate regimes is unclear. ${ }^{10}$ Therefore, to investigate the effect of a different exchange rate regime on the results, the sample period is divided into two sub-periods: (1) pre-1972 (up to and including 1971), corresponding to the fixed exchange rate regime; and (2) post-1972 (1972 to 2006), corresponding to the floating exchange rate period. The results shown in Table 8 are ranked in ascending order according to the estimated $\beta$ coefficient over the pre-1972 period. There is a large variation in the estimated $\beta$ coefficient and the proportion of global risk between the two sub-periods. Over the pre-1972 sub-period, the estimated $\beta$ values range from as low as -0.67 for rice to as high as 3.78 for rubber and are significant for only 12 out of 33 cases (column 2). Panel A of Figure 8 shows the change in the $\beta$ coefficient from the preto post-1972 period. The shaded rectangle contains all slope coefficient pairs for each of the 33 commodities where the base of the shaded rectangle exceeds its height, implying that the dispersion of $\beta$ coefficient is much larger in the pre-1972 period.

In addition, $R^{2}$ is very low during the pre-1972 period, implying the greater part of the commodity price volatility observed during this sub-period is the result of idiosyncratic risk factors unique to each primary commodity. Interestingly, 25 out of the 33 commodities experience increasing $R^{2}$ values when moving from the pre- to post-1972 period. Panel B of Figure 8 shows that only eight out of the 33 points lie below the 45-degree line, which accords with the idea that global risk components

\footnotetext{
10 Mussa (1986) showed that floating exchange rates have contributed substantially to the variability of real exchange rate than under the Bretton Woods regime. Since the real appreciation or depreciation of the US dollar has profound effects on the prices of primary commodities in all other currencies, higher fluctuations in the exchange rates translate into higher instability of commodity prices. See Sjaastad and Scacciavillani (1996) and Sjaastad (2008).
} 
Table 8

Sensitivity and Risk Components Across Exchange Rate Regime, 1948-2006

\begin{tabular}{|c|c|c|c|c|c|c|c|c|c|c|c|}
\hline \multirow[b]{3}{*}{$\begin{array}{c}\text { Commodity } \\
\text { (1) }\end{array}$} & \multicolumn{5}{|c|}{$1948-1971$} & \multicolumn{6}{|c|}{$1972-2006$} \\
\hline & \multicolumn{2}{|l|}{$\beta_{i}$} & \multirow[b]{2}{*}{ DW } & \multicolumn{2}{|c|}{ Risk Component (\%) } & \multicolumn{2}{|l|}{$\beta_{i}$} & \multirow[b]{2}{*}{ DW } & \multicolumn{2}{|c|}{ Risk Component (\%) } & \multirow[b]{2}{*}{$\beta_{i}$ Rank } \\
\hline & $\begin{array}{c}\text { Coefficient } \\
\text { (2) }\end{array}$ & $\begin{array}{l}\text { SE } \\
(3)\end{array}$ & & $\begin{array}{l}\text { Global } \\
\text { (5) }\end{array}$ & $\begin{array}{l}\text { Commodity- } \\
\text { Specific } \\
\text { (6) }\end{array}$ & $\begin{array}{c}\text { Coefficient } \\
\text { (7) }\end{array}$ & $\begin{array}{l}\text { SE } \\
(8)\end{array}$ & & $\begin{array}{c}\text { Global } \\
\text { (10) }\end{array}$ & $\begin{array}{c}\text { Commodity- } \\
\text { Specific } \\
(11)\end{array}$ & \\
\hline 1. Rice & -0.67 & 0.49 & 1.06 & 8.25 & 91.78 & $1.39 * *$ & 0.22 & 2.10 & 54.26 & 45.74 & 25 \\
\hline 2. Iron ore & -0.33 & 0.48 & 1.11 & 2.19 & 97.81 & 0.04 & 0.18 & 1.21 & 0.17 & 99.83 & 1 \\
\hline 3. Crude oil & -0.31 & 0.38 & 1.23 & 3.08 & 96.92 & $1.45 * *$ & 0.37 & 2.09 & 31.60 & 68.40 & 27 \\
\hline 4. Bauxite & -0.01 & 0.42 & 2.06 & 0.00 & 100.00 & 0.33 & 0.20 & 2.31 & 11.78 & 88.22 & 6 \\
\hline 5. Aluminium & 0.02 & 0.19 & 1.25 & 0.06 & 99.94 & $0.81 * *$ & 0.22 & 1.92 & 29.30 & 70.70 & 11 \\
\hline 6. Nickel & 0.03 & 0.22 & 1.51 & 0.09 & 99.91 & $1.17 * *$ & 0.33 & 1.91 & 27.75 & 72.25 & 22 \\
\hline 7. Phosphate rock & 0.07 & 0.39 & 1.96 & 0.16 & 99.84 & $0.71 *$ & 0.35 & 1.75 & 11.30 & 88.70 & 10 \\
\hline 8. Tobacco & 0.12 & 0.48 & 2.67 & 0.29 & 99.71 & 0.07 & 0.13 & 1.53 & 0.95 & 99.05 & 2 \\
\hline 9. Tea & 0.14 & 0.53 & 1.59 & 0.35 & 99.65 & $0.53 *$ & 0.24 & 2.36 & 13.22 & 86.79 & 8 \\
\hline 10. Wheat & 0.19 & 0.28 & 1.43 & 2.11 & 97.89 & $0.96 * *$ & 0.20 & 1.85 & 41.98 & 58.02 & 17 \\
\hline 11. Maize & 0.23 & 0.52 & 1.21 & 0.97 & 99.03 & $1.02 * *$ & 0.17 & 2.30 & 53.58 & 46.42 & 19 \\
\hline 12. Bananas & 0.26 & 0.35 & 1.68 & 2.56 & 97.44 & 0.12 & 0.19 & 2.19 & 1.20 & 98.80 & 4 \\
\hline 13. Palm oil & 0.30 & 0.59 & 2.06 & 1.23 & 98.77 & $1.56 * *$ & 0.27 & 1.89 & 49.75 & 50.25 & 30 \\
\hline 14. Beef & 0.35 & 0.36 & 2.02 & 4.47 & 95.53 & 0.31 & 0.18 & 1.92 & 8.29 & 91.71 & 5 \\
\hline 15. Sorghum & 0.51 & 0.37 & 2.23 & 8.27 & 91.73 & $0.90 * *$ & 0.16 & 2.19 & 49.77 & 50.23 & 14 \\
\hline 16. Oranges & 1.01 & 0.63 & 2.48 & 10.80 & 89.20 & 0.11 & 0.19 & 2.42 & 1.02 & 98.98 & 3 \\
\hline 17. Coconut oil & 1.10 & 0.66 & 2.01 & 11.65 & 88.35 & $2.34 * *$ & 0.36 & 1.65 & 56.28 & 43.72 & 32 \\
\hline 18. Logs & $1.25^{*}$ & 0.55 & 2.43 & 19.54 & 80.46 & $0.88 * *$ & 0.27 & 2.24 & 24.06 & 75.94 & 12 \\
\hline 19. Cocoa & 1.31 & 1.16 & 2.04 & 5.68 & 94.32 & $0.93 * *$ & 0.30 & 1.32 & 22.66 & 77.34 & 15 \\
\hline 20. Groundnut meal & $1.35^{* *}$ & 0.29 & 2.67 & 51.73 & 48.27 & $0.98 * *$ & 0.33 & 2.21 & 25.57 & 74.43 & 18 \\
\hline
\end{tabular}


Table 8 (continued)

Sensitivity and Risk Components Across Exchange Rate Regime, 1948-2006

\begin{tabular}{|c|c|c|c|c|c|c|c|c|c|c|c|}
\hline \multirow[b]{3}{*}{ Commodity } & \multicolumn{5}{|c|}{$1948-1971$} & \multicolumn{6}{|c|}{$1972-2006$} \\
\hline & \multicolumn{2}{|l|}{$\beta_{i}$} & \multirow[b]{2}{*}{ DW } & \multicolumn{2}{|c|}{ Risk Component (\%) } & \multicolumn{2}{|l|}{$\beta_{i}$} & \multirow[b]{2}{*}{ DW } & \multicolumn{2}{|c|}{ Risk Component (\%) } & \multirow{3}{*}{$\beta_{i}$ Rank } \\
\hline & Coefficient & SE & & Global & $\begin{array}{l}\text { Commodity- } \\
\text { Specific }\end{array}$ & Coefficient & $\mathrm{SE}$ & & $\overline{\text { Global }}$ & $\begin{array}{l}\text { Commodity- } \\
\text { Specific }\end{array}$ & \\
\hline (1) & $(2)$ & (3) & $(4)$ & $(5)$ & (6) & $(7)$ & $(8)$ & $(9)$ & (10) & (11) & \\
\hline 21. Tin & $1.40 * *$ & 0.46 & 2.23 & 30.79 & 69.21 & $1.21 * *$ & 0.21 & 2.42 & 50.58 & 49.42 & 23 \\
\hline 22. Cotton & $1.40 * *$ & 0.45 & 1.77 & 31.45 & 68.55 & $0.96 * *$ & 0.23 & 2.63 & 34.52 & 65.48 & 16 \\
\hline 23. Coffee & $1.42 *$ & 0.68 & 1.63 & 17.09 & 82.91 & 0.66 & 0.39 & 2.00 & 7.80 & 92.20 & 9 \\
\hline 24. Copra & 1.43 & 0.78 & 2.37 & 13.89 & 86.11 & $2.45 * *$ & 0.34 & 1.66 & 61.64 & 38.36 & 33 \\
\hline 25. Groundnut oil & $1.50 * *$ & 0.50 & 1.95 & 29.85 & 70.15 & $1.02 * *$ & 0.31 & 2.22 & 24.77 & 75.23 & 20 \\
\hline 26. Copper & 1.57 & 0.79 & 1.85 & 15.65 & 84.35 & $1.50 * *$ & 0.21 & 1.41 & 61.50 & 38.50 & 28 \\
\hline 27. Soybean meal & $1.70 * *$ & 0.56 & 2.08 & 30.95 & 69.05 & $0.89 * *$ & 0.29 & 2.30 & 22.33 & 76.31 & 13 \\
\hline 28. Sugar & 1.86 & 1.55 & 1.82 & 6.41 & 93.59 & $1.53 * *$ & 0.48 & 2.03 & 23.69 & 76.31 & 29 \\
\hline 29. Soybeans & $2.07 * *$ & 0.54 & 2.34 & 41.24 & 58.76 & $1.07 * *$ & 0.16 & 2.31 & 56.33 & 43.67 & 21 \\
\hline 30. Lead & $2.42 * *$ & 0.70 & 2.26 & 35.97 & 64.03 & $1.41 * *$ & 0.24 & 2.32 & 50.05 & 49.95 & 26 \\
\hline 31. Zinc & $2.63 * *$ & 0.72 & 2.24 & 38.77 & 61.23 & $1.64 * *$ & 0.26 & 1.23 & 55.38 & 44.62 & 31 \\
\hline 32. Jute & $2.90 *$ & 1.03 & 2.16 & 27.52 & 72.48 & 0.48 & 0.31 & 2.15 & 7.21 & 92.79 & 7 \\
\hline 33. Rubber & $3.78 * *$ & 0.98 & 2.14 & 41.62 & 58.38 & $1.38 * *$ & 0.18 & 1.97 & 64.61 & 35.39 & 24 \\
\hline Mean & 1.00 & & & & & 0.99 & & & & & \\
\hline
\end{tabular}

Notes: 1. Double and single asterisks ( $* *$ and $*$ ) denote estimated coefficients significantly different from zero at the $1 \%$ and $5 \%$ levels, respectively.

2. Column 12 shows the ranking of each commodity from 1 to 33 . Commodity whose rank is higher implies higher estimated $\beta$ coefficient in comparison with the remaining commodities in the data set.

3. $\mathrm{SE}=$ standard error. $\mathrm{DW}=$ Durbin-Watson statistic. 


\section{Figure 8}

Sensitivity and Risk Components Across Exchange Rate Regime, 1948-2006

\section{A. Slope Coefficient, $\beta_{i}$}

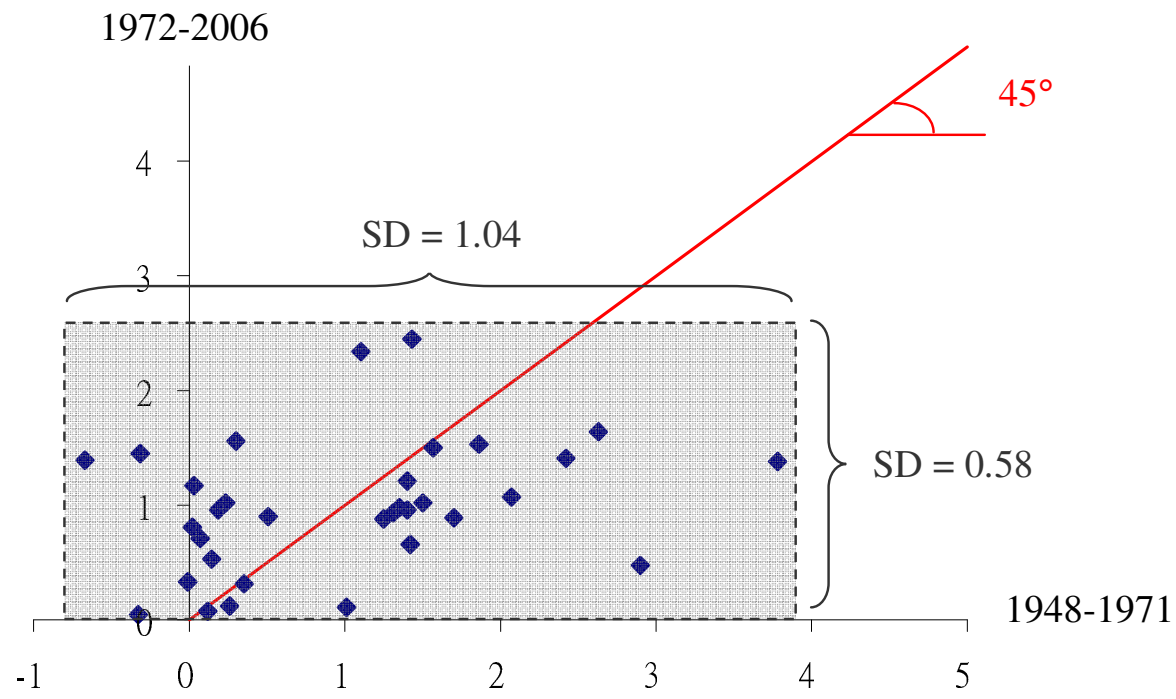

\section{B. Share of Global Risk Component, $\mathbf{R}^{2}(\%)$}

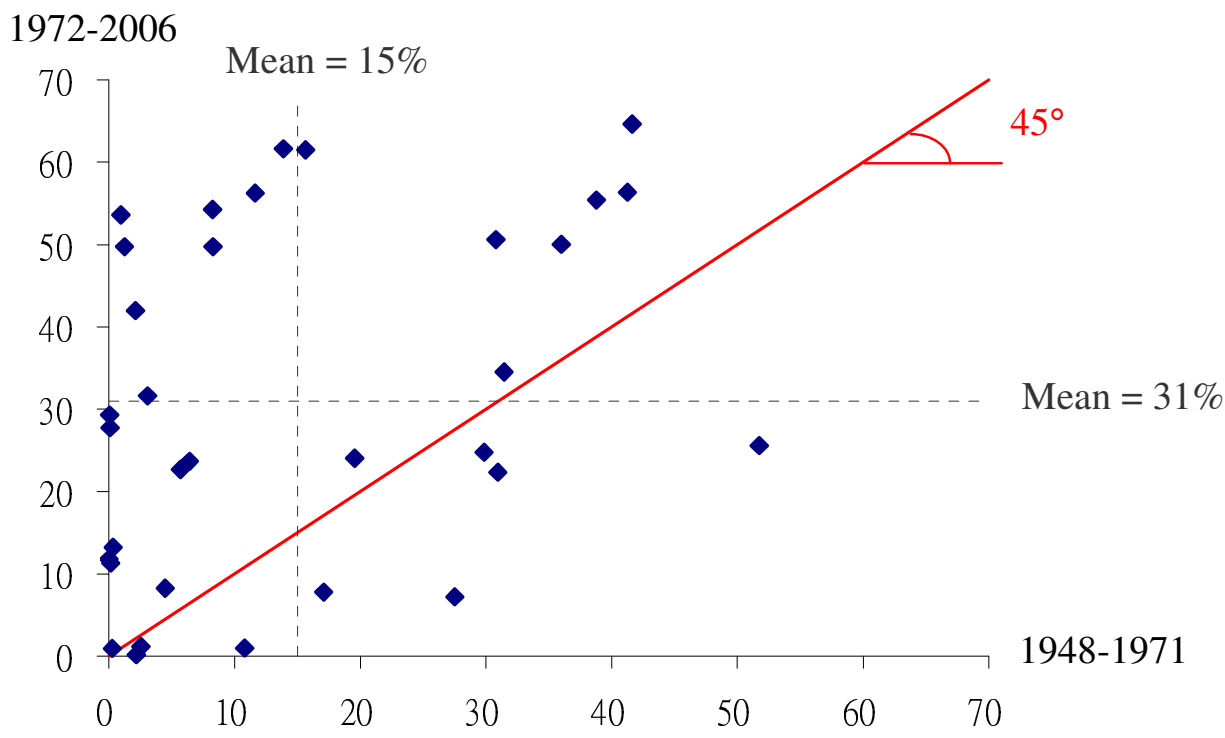

have become relatively more important in explaining commodity price volatility under a floating exchange rate regime. Figure 9 shows that the average $R^{2}$ values across 33 commodities increased from 15 percent (Panel A) to 31 percent (Panel B) between the two sub-periods, indicating that variations in the prices of these commodities are more closely linked to global macroeconomic factors common to all 
commodities. In other words, systematic risk factors have become more important over the floating exchange rate regime. The last column of Table 8 is another feature worthy of note. The column expresses the commodity rank according to its $\beta$ coefficient over the second sub-period to assist in cross-commodity comparisons between the two sub-periods: the higher the rank for the commodity under investigation, the higher the magnitude of the corresponding $\beta$ estimates. Of 15 commodities that have estimated $\beta$ of less than unity over 1948 to 1971,12 experienced an increase in the level of sensitivity common to global fluctuations in the second sub-period. Conversely, in 15 out of 18 cases with levels of sensitivity originally above unity, a decrease in the magnitude of the $\beta$ coefficient over the two sub-periods was experienced. As a consequence, the dispersion of $\beta$ coefficients among the 33 commodities decreased substantially over the two periods, from 4.45 down to 2.41 , the estimated $\beta$ ranging from as low as 0.04 to 2.45 over the second sub-period. Overall, the $\beta$ estimates are not statistically different from one for 20 out of 33 commodities during the post-1972 period.

\section{Figure 9}

\section{Proportion of Common Global Risk in Commodity Price Volatility}

\section{A. Fixed Exchange Rate Regime, 1948-1971}

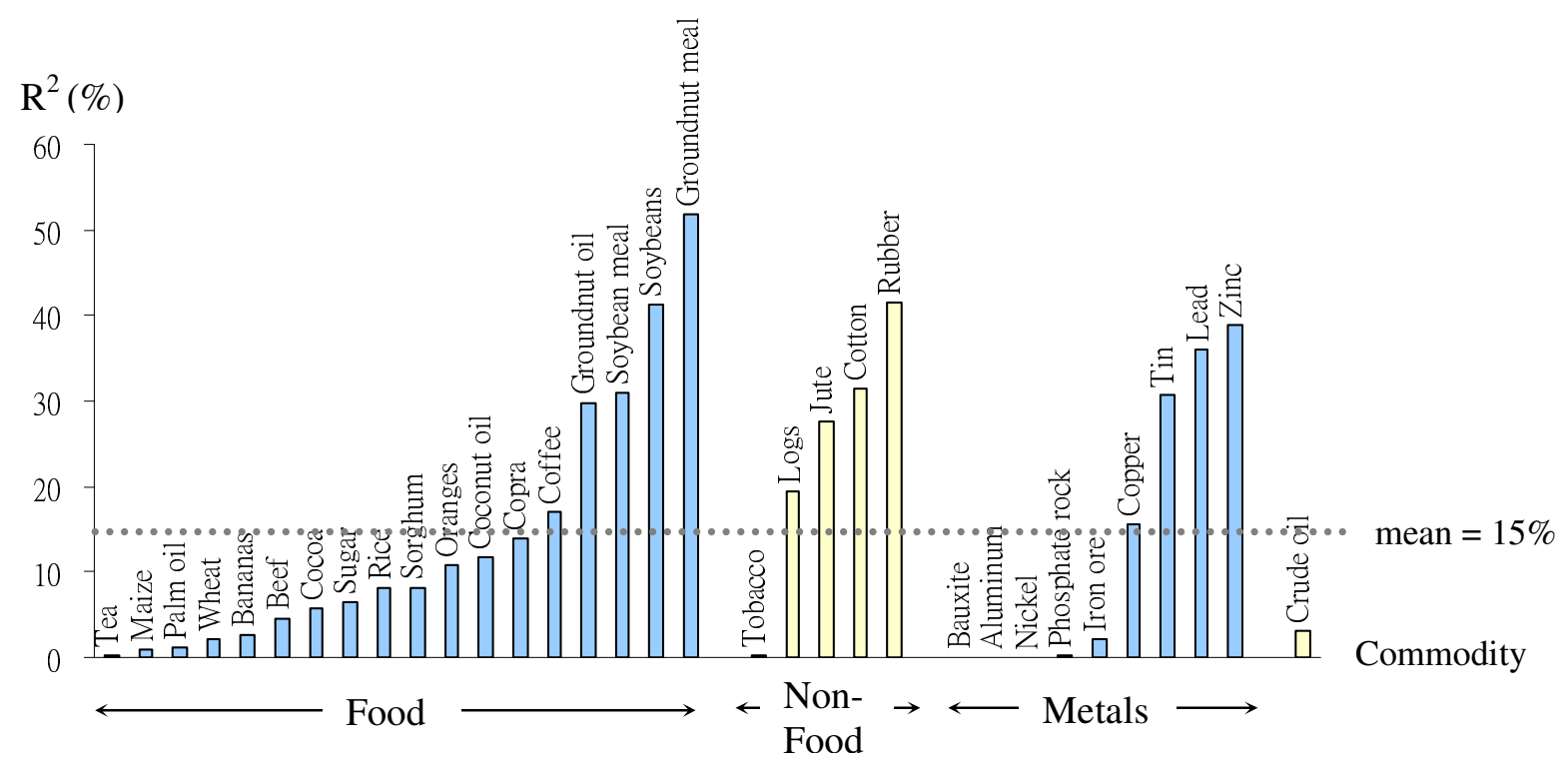


Figure 9 (continued)

Proportion of Common Global Risk in Commodity Price Volatility

B. Managed Floating Exchange Rate Regime, 1972-2006

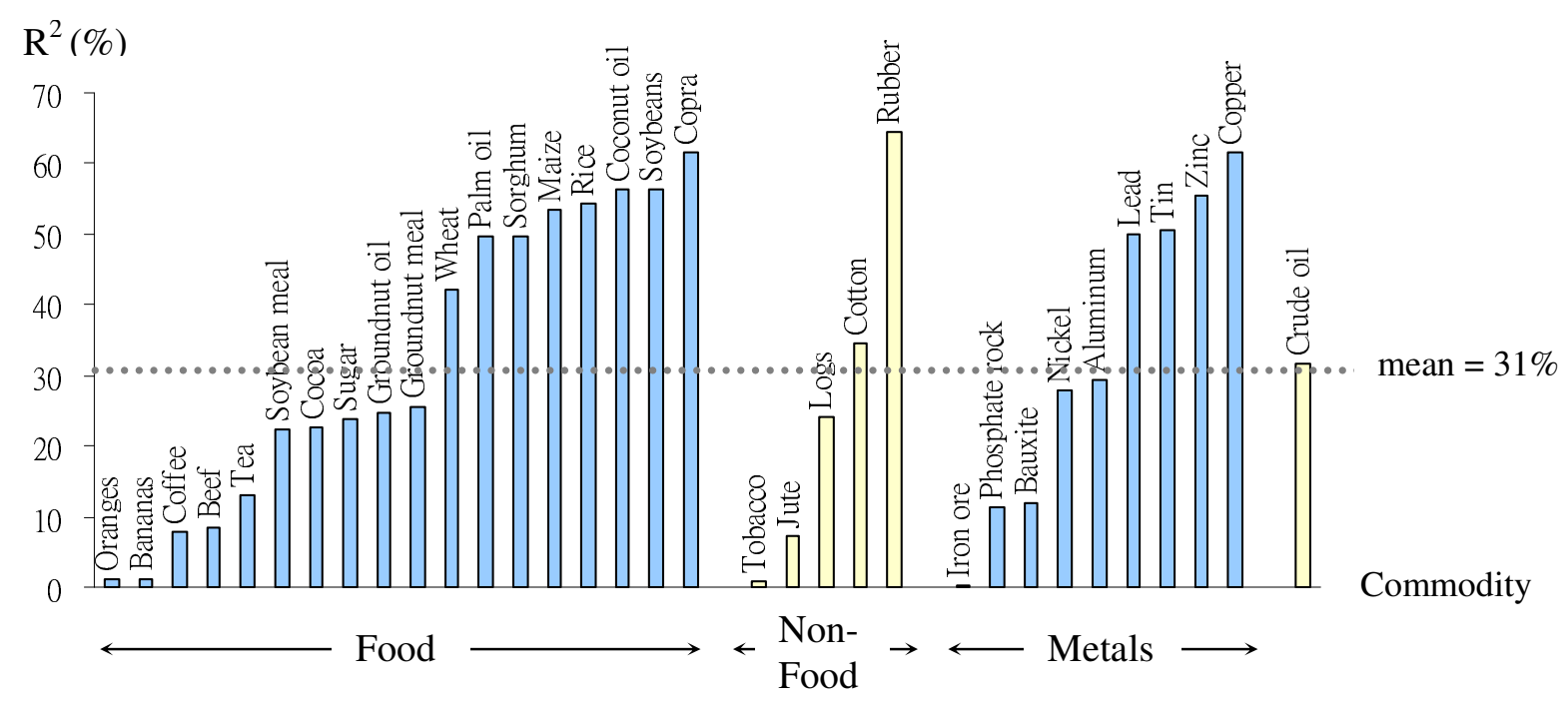

Overall, the regression results shown in Table 8 and Figure 9 suggest that over time, systematic risk components common to broad sets of internationally-traded primary commodities have become relatively more important in explaining overall individual commodity price variations. In other words, commodity-specific risk components have gradually lost their significant status in describing the overall volatility of annual commodity price returns.

\section{CONCLUSION}

The main purpose of this paper is to study the long-term behaviour of world commodity prices. Specifically, we examined the volatility of price movements, its two main components-within-group and between-group-and the proportion of global and commodity-specific volatility in explaining overall price variations. The main results are summarized as follows. There is strong evidence that prices of world primary commodities are associated with substantial volatility. During the period from 1948 to 2006, prices of many commodities were found to fluctuate from below 50 percent to above 100 percent per year relative to their average prices. In addition, our results show a strong tendency for the level of price volatility to be 1.3 times higher under floating than under fixed exchange rate regimes. By means of a simple decomposition, it is shown that the cross-sectional volatility of commodity prices can 
be decomposed into within-group and between-group components. The betweengroup component accounts for only one-fifth of total price volatility, whereas the within-group component takes up the remaining four-fifths, indicating that shocks impacting the commodity market have larger effects on commodities that belong to the same group, while the spill-over effects to other commodity groups are kept to the minimum. Finally, the CAPM is used as a loose framework to differentiate global macroeconomic risk factors from commodity-specific risk in explaining annual variation in commodity price returns. On average, roughly 31 percent of price volatility can be attributed to global macroeconomic factors over the period 1972 to 2006, in comparison to 15 percent during the pre-1972 period. In other words, during the latter period, the other 69 percent of overall variation may be regarded as commodity-specific risk that can be reduced through proper diversification. In addition, the estimated $\beta$ coefficient - the response of commodity return to changes in world commodity return-moved toward unity in the post-1972 period, implying that the price of an individual primary commodity increases by one percent when the overall price index increases by the same amount.

Several qualifications to our results have to be kept in mind. First, this paper adopts an equal-weighted average price approach in constructing the composite commodity price index and sub-indices. Second, as pointed out by Valadkhani and Layton (2006), the portfolio theory underlying CAPM can only be used as a loose framework in factoring out global risk from commodity specific risk. 


\section{APPENDIX A1}

\section{The Composition of Sub-Indices Over Time}

The non-fuel composite price index used in this paper can be further broken down into three sub-indices including eighteen food commodities, five non-food agricultural commodities and nine metals commodities. The sub-indices were selected to analyse the behaviour of commodity prices across different commodity categories, and to ensure comparability with earlier work. The respective weight of each group in the composite price index is different depending on the number of nonfuel primary commodities within each group. As shown in Table A1.1, the weight is $56 \%$ for food, $16 \%$ for non-food industrial commodities and $28 \%$ for metals. Each primary commodity in question receives equal weight in the price index, therefore its respective share is fixed throughout the whole sample period except in 1995, 1999 and 2005, when price series were discontinued for bauxite, groundnut meal and jute. In these instances, the share (i.e., 1/32, as crude oil is excluded from the calculation of the non-fuel commodity price index) previously assigned to the commodity that was phased out is evenly distributed among the remaining primary commodities.

See Table A1.2 for details of the expenditure share allocated to each sub-group over the sample period 1948 to 2006. 
Table A1.1

Composition of Three Main Sub-Indices

\begin{tabular}{|c|c|c|c|}
\hline & \multicolumn{3}{|c|}{ Sub-Category } \\
\hline & $\begin{array}{l}\text { Food } \\
\text { (1) }\end{array}$ & $\begin{array}{l}\text { Non-Food } \\
\text { (2) }\end{array}$ & $\begin{array}{c}\text { Industrial Metals } \\
\text { (3) }\end{array}$ \\
\hline 1. & Bananas & Cotton & Aluminium \\
\hline 2. & Beef & Jute & Bauxite \\
\hline 3. & Cocoa & Logs & Copper \\
\hline 4. & Coconut Oil & Rubber & Iron Ore \\
\hline 5. & Coffee & Tobacco & Lead \\
\hline 6. & Copra & & Nickel \\
\hline 7. & Groundnut Meal & & Phosphate Rock \\
\hline 8. & Groundnut Oil & & Tin \\
\hline 9. & Maize & & Zinc \\
\hline 10. & Oranges & & \\
\hline 11. & Palm Oil & & \\
\hline 12. & Rice & & \\
\hline 13. & Sorghum & & \\
\hline 14. & Soybean Meal & & \\
\hline 15. & Soybeans & & \\
\hline 16. & Sugar & & \\
\hline 17. & Tea & & \\
\hline 18. & Wheat & & \\
\hline Weight & $56.25 \%$ & $15.63 \%$ & $28.13 \%$ \\
\hline
\end{tabular}

Note: Weight represents the share of each sub-index within the composite price index. The index used is an equal-weighted commodity price index.

Table A1.2

Share of Groups Over Time, 1948-2006

\begin{tabular}{cccccc}
\hline \hline & & \multicolumn{3}{c}{ Share } & \\
\cline { 3 - 5 } & & Food & Non-Food & Metals & Total \\
Period & Commodities & $\bar{W}_{1 t}$ & $\bar{W}_{2 t}$ & $\bar{W}_{3 t}$ & $\sum_{g=1}^{3} \bar{W}_{g t}$ \\
$(1)$ & $(2)$ & $(3)$ & $(4)$ & $(5)$ & $(6)$ \\
\hline $1948-1994$ & 32 & 56.25 & 15.63 & 28.13 & 100.00 \\
$1995-1998$ & 31 & 58.06 & 16.13 & 25.81 & 100.00 \\
$1999-2004$ & 30 & 56.67 & 16.67 & 26.67 & 100.00 \\
$2005-2006$ & 29 & 58.62 & 13.79 & 27.59 & 100.00 \\
\hline
\end{tabular}

Notes: 1. All entries are to be divided by 100.

2. All entries are simple averages over the corresponding periods.

3. Price series for bauxite (metals) were phased out in 1995, groundnut meal (food) in 1999 and jute (non-food) in 2005. 


\section{References}

Bidarkota, P. and Crucini, M. J. 2000, "Commodity Prices and the Terms of Trade", Review of International Economics, vol. 8, no. 4, pp. 647-666.

Bomberger, W. A. and Makinen, G. E. 1993, "Inflation and Relative Price Variability: Parks' Study Reexamined", Journal of Money, Credit, and Banking, vol. 25, no. 4, pp. 854-861.

Cashin, P. and McDermott, C. J. 2002, "The Long-Run Behaviour of Commodity Prices: Small Trends and Big Variability" IMF Working Paper, no. 49.

Chan, A. and Clements, K. W. 2007, "The International Volatility of Growth", Economics Program Discussion Paper, UWA Business School, The University of Western Australia, no. 07-10, pp. 1-34.

Chu, K. and Morrison, T. K. 1984, "The 1981-82 Recession and Non-Oil Primary Commodity Prices", IMF Staff Papers, vol. 31, pp. 93-140.

Clements, K. W. 2004, “Three Facts about Marijuana Prices”, Australian Journal of Agricultural and Resource Economics, vol. 48. no. 2, pp. 271-300.

Cuddington, J. T. and Liang, H. 1999, "Commodity Price Volatility Across Exchange Rate Regimes", Working Paper.

Cuddington, J. T. and Liang, H. 2003, "Commodity Price Volatility Across Exchange Rate Regimes”, Working Paper.

Deaton, A. 1999, "Commodity Prices and Growth in Africa", The Journal of Economic Perspectives, vol. 13, no. 3, pp. 23-40.

Deaton, A. and Laroque, G. 1992, "On the Behaviour of Commodity Prices", Review of Economic Studies, vol. 59, no. 198, pp. 1-23.

Grilli, E. R. and Yang, M. C. 1988, "Primary Commodity Prices, Manufactured Goods Prices, and the Terms of Trade of Developing Countries: What the Long Run Shows", The World Bank Economic Review, vol. 2, no. 1, pp. 1-47.

Jaramillo, C. F. 1999, "Inflation and Relative Price Variability: Reinstating Parks' Results", Journal of Money, Credit, and Banking, vol. 31, no. 3, pp. 375-385.

Kroner, K. F., Kneafsey, D. P. and Claessens, S. 1993, "Forecasting Volatility in Commodity Markets", World Bank Policy Research Working Paper, no. 1226.

Lintner, J. 1965, "The Valuation of Risk Assets and Selection of Risky Investments in Stock Portfolios and Capital Budgets", Review of Economics and Statistics, vol. 47, pp. 13-37.

Markowitz, H. 1959, Portfolio Selection: Efficient Diversification of Investments, Wiley, New York.

Mossin, J. 1966, “Equilibrium in Capital Market”, Econometrica, vol. 34, pp. 768-783.

Mussa, M. 1986, "Nominal Exchange Rate Regimes and the Behavior of Real Exchange Rates: Evidence and Implications", Carnegie-Rochester Conference Series on Public Policy, North Holland Publishing Company, Amsterdam, no. 25, pp.117-213. 
Parks, R. W. 1978, "Inflation and Relative Price Variability", Journal of Political Economy, vol. 86, no. 1, pp. 79-95.

Pindyck, R. S. 2001, "Volatility and Commodity Price Dynamics", Center for Energy and Environmental Policy Research Working Paper, no. 01-007.

Pfaffenzeller, S., Newbold, P. and Rayner, A. 2007, "A Short Note on Updating the Grilli and Yang Commodity Price Index", The World Bank Economic Review, vol. 21, no. 1, pp. 151-163.

Reinhart, C. M. and Wickham, P. 1994, "Commodity Prices: Cyclical Weakness or Secular Decline?”, IMF Staff Papers, vol. 41, pp. 175-213.

Sharp, W. F. 1964, "Capital Asset Prices: A Theory of Market Equilibrium Conditions of Risk", Journal of Finance, vol. 19, pp. 425-442.

Sjaastad, L. A. 2008, "The Price of Gold and the Exchange Rates: Once Again", Resources Policy, vol. 33, pp. 118-124.

Sjaastad, L. and Scacciavillani, F. 1996, "The Price of Gold and the Exchange Rate", Journal of International Money and Finance, vol. 15, pp. 879-897.

Valadkhani, A. and Layton, A. 2006, "A Cross-Country Analysis of Export Prices in OECD Countries", Economic Papers, vol. 25, no. 4, pp. 331-346.

Vining, D. R., Jr. and Elwertowski, T. C. 1976, "The Relationship between Relative Prices and the General Price Level”, The American Economic Review, vol. 66, no. 4, pp. 699-708.

Yamey, B. S. 1992, "The Tin Crisis (1985-86) and Futures Trading", Economic Record, vol. 68, pp. 10-15. 